\title{
The Immunological Dilemma: Cellular Innate and Adaptive Immune Re- sponse Versus Human Acute Myeloid Leukemia
}

\author{
Elisabeth Ersvaer*, $^{*}$, Astrid M. Olsnes ${ }^{1}$ and $\emptyset_{\text {stein Bruserud }}{ }^{1,2}$ \\ ${ }^{1}$ Institute of Medicine, University of Bergen and ${ }^{2}$ Haukeland University Hospital, Bergen, Norway
}

\begin{abstract}
It is generally accepted that acute myelogenous leukemia (AML) patients are immunocompromized. On the other hand, antileukemic immune reactivity is important for the improved survival of AML patients treated with allogeneic stem cell transplantation and antileukemic immunotherapy is also considered for patients treated with conventional chemotherapy. In this article, we review the available studies of disease- and therapy- induced immune dysfunctions in AML patients, including the function of the cellular innate and adaptive immune system of AML patients (i) with newly diagnosed disease before treatment, (ii) immunological functions of AML patients with severe therapy induced cytopenia before hematopoietic reconstitution; and (iii) the immune reconstitution following the initial period of hematopoietic reconstitution after autologous and allogeneic stem cell transplantation. A more detailed knowledge about the immune systems of these patients is essential for an optimal design of future clinical immunotherapy studies in AML.
\end{abstract}

Keywords: Acute myelogenous leukemia, Immune system, Chemotherapy.

\section{INTRODUCTION}

Acute myelogenous leukemia (AML) is characterized by clonal proliferation of immature myeloid precursors and an arrest in the maturation of these cells [1]. This results in accumulation of a leukemic blast population in the bone marrow $(\mathrm{BM})$ and eventually in the peripheral blood (PB). The bone marrow infiltration causes a decrease in the production of and thereby a reduction in the peripheral blood levels of mature myeloid cells; resulting in thrombocytopenia, anemia and granulocytopenia.

It is well known that AML patients are immunocompromized and have an increased risk of infections [1]. Fatal infections are an important cause of the treatment-related mortality especially in elderly individuals. AML patients often have neutropenia initially due to the disease and later eventually due to intensive chemotherapy. However, as will be seen from the studies reviewed below these patients can also have additional disease- or therapy-induced dysfunctions of the cellular immune system. One would expect that these dysfunctions differ between patients due to for example differences in AML cell phenotypes, chemotherapy regimen and age-dependent alterations of the immune system.

\section{THE IMMUNE SYSTEM IN PATIENTS WITH UN- TREATED AML}

Natural Killer Cells: The Importance of AML Cell Burden, NCR ${ }^{\text {dull }}$ NK Cell Phenotype and NK-Inhibitory AML Cell Phenotype

Natural killer (NK) cells (Table 1) are a heterogeneous lymphoid population comprising $10-15 \%$ of all peripheral lymphocytes, and they seem to be involved in antitumor activity as well as tumor surveillance [2,3]. Elevated levels of lymphocytes with NK phenotype have been reported at the

*Address correspondence to this author at the Elisabeth Ersvær, Section for Haematology, Institute of Medicine, University of Bergen, N-5021 Bergen, Norway; Tel: +47 5597 30 76; Fax: +47 559729 50;

E-mail: elisabeth.ersvar@med.uib.no time of diagnosis in AML [4]. CD56 $6^{+}, \mathrm{CD} 16^{+} \mathrm{CD} 2^{+}$and $\mathrm{CD} 16^{+} \mathrm{CD} 2^{-} \mathrm{NK}$ cells were then found significantly increased in peripheral blood, but only the $\mathrm{CD}^{2} 6^{+} \mathrm{NK}$ cells were additionally increased in bone marrow [4]. When these authors divided the AML cases into two groups according to the absolute number of circulating NK cells, the patients with the highest levels also showed an increased proportion of circulating leukemic blasts [4].

Despite the increased NK cell levels, several other studies report NK cell dysfunction [5-8] or impeded NK cell maturation [9] in patients with cancer, including preleukemic myelodysplastic syndromes (MDS) as well as leukemia. In accordance with this, it has been suggested that NK cells in leukemic patients display a more inhibitory $A B$ haplotype killer cell immunoglobulin-like receptor (KIR) phenotype compared to healthy controls (Table 2, Fig. 1) [10]. Additionally, it is hypothesized that leukemic cells may have evolved an escape mechanism from immune surveillance based on the dominance of inhibitory KIR ligands over activating KIR ligands displayed on the leukemic cells (see Table 3) [11].

Recently, deficient expression of the natural cytotoxicity receptors $\left(\mathrm{NCR}^{\text {dull}}\right.$; $\mathrm{NKp} 30, \mathrm{NKp} 44$ and $\left.\mathrm{NKp} 46\right)$ in NK cells from AML patients was reported (Table 3) [5, 12]. This $\mathrm{NCR}^{\text {dull }}$ phenotype was possibly induced by direct contact with leukemia blasts and NK cells, and not via the cytokine network. Moreover, $\mathrm{NCR}^{\text {dull }}$ NK cell phenotype was associated with poor survival of AML patients [12]. The influences of the leukemic cells upon the NK lymphocytes still remain unclear. However, based on the above mentioned reports, it is justified to state that both qualitative as well as quantitative disturbances in the NK cell system can be detected in AML patients (Table 2).

Dendritic Cells: Immature Leukemic Dendritic Cells as a Cause of Immunosuppression?

Dendritic cells (DCs) (Table 1) are central in the presentation of tumor antigens to the adaptive arms of the immune 
Table 1. Some of the Circulating Cells of the Immune System

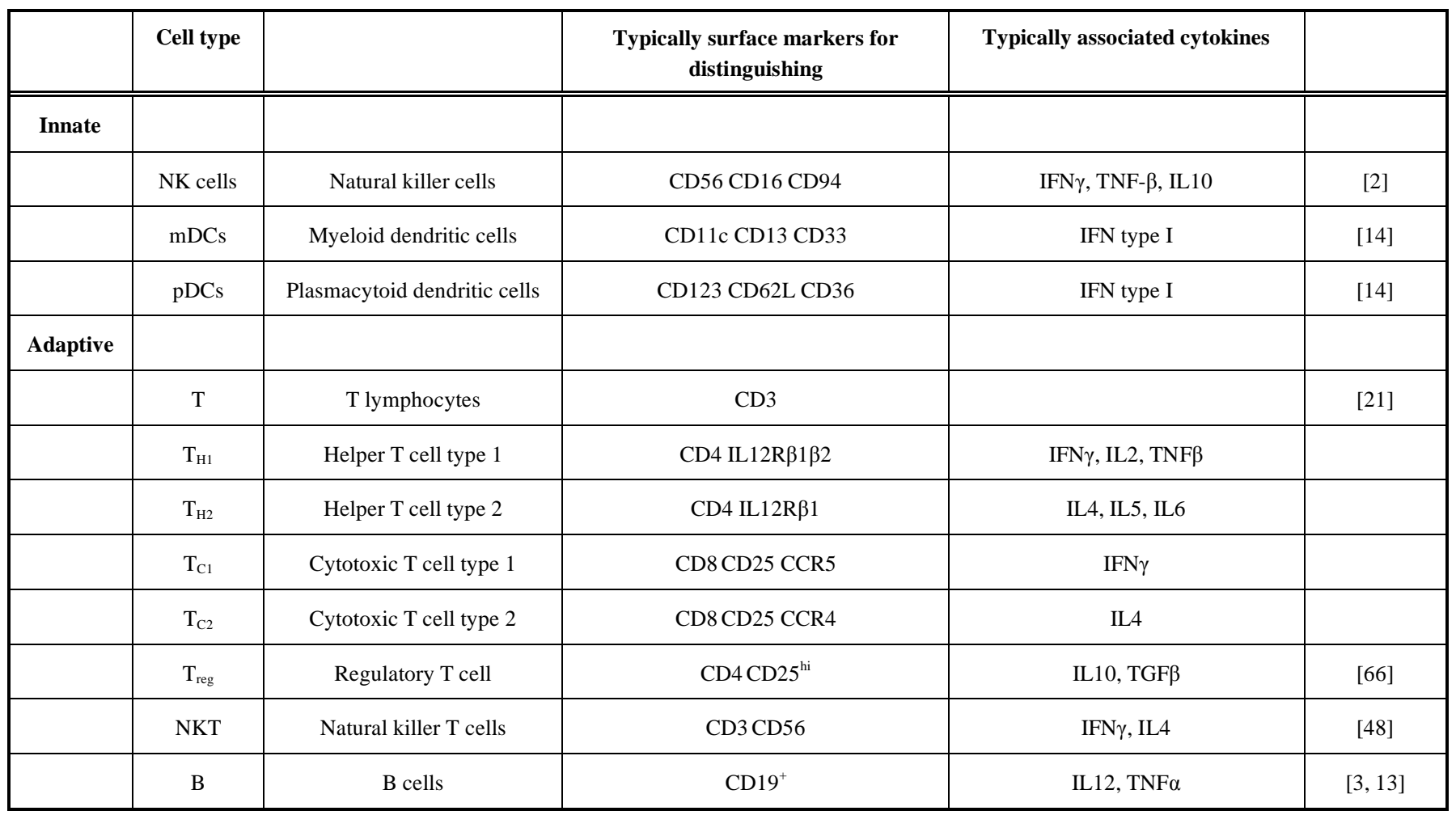

An overview of the immune cells comprising the cellular innate and adaptive immune system, however, there are heterogeneity within each subsets that are not shown in this table.

Table 2. The Cellular Immune System in Untreated AML Patients

\begin{tabular}{|c|c|c|}
\hline Natural killer cells & $\begin{array}{l}\text { Increased } \mathrm{CD}^{+} 6^{+}, \mathrm{CD} 16^{+} \mathrm{CD} 2^{+} \text {, and } \mathrm{CD} 16^{+} \mathrm{CD} 2^{-} \mathrm{NK} \text { cell levels } \\
\text { More inhibitory killer cell immunoglobulin-like receptors (KIRs) expressed } \\
\text { Deficient expression of natural cytotoxicity receptors }\left(\mathrm{NCR}^{\text {dull }}\right) \\
\mathrm{NCR}^{\text {dull }} \text { expression correlate with worse outcome }\end{array}$ & $\begin{array}{c}{[4]} \\
{[10]} \\
{[5,12]} \\
{[12]}\end{array}$ \\
\hline $\mathbf{T}$ cells & $\begin{array}{l}\text { Close to normal } \mathrm{CD} 4 / \mathrm{CD} 8 \text { ratio } \\
\text { Normal absolute numbers of } \mathrm{CD} 3^{+} \mathrm{CD} 8^{+} \text {and } \mathrm{CD} 3^{+} \mathrm{CD} 8^{-} \\
\text {Increased } \mathrm{PB} \mathrm{CD} 8^{+} \mathrm{CD} 57^{+} \mathrm{T} \text { cells within the } \mathrm{CD} 8^{+} \text {cells } \\
\text { Normal } \mathrm{T}_{\mathrm{H} 1} \text { and } \mathrm{T}_{\mathrm{H} 2} \text { cytokine profile } \\
\text { Reduced } \mathrm{T} \text { cell } \mathrm{CD} 3-\zeta \text { expression } \\
\text { Functional within a microenvironment dominated by AML cells } \\
\text { Decreased } \mathrm{V} \alpha 24^{+} \mathrm{NKT} \text { cells correlated with worse prognosis } \\
\text { Increased } \mathrm{CD} 3^{+} \mathrm{CD} 56^{+} \mathrm{NKT} \text { cells in PB } \\
\text { Increased proportions of } \mathrm{CD} 4^{+} \mathrm{CD} 25^{\mathrm{HIGH}} \mathrm{T}_{\text {reg }} \text { cells } \\
\text { AML cells IDO expression correlates with increased numbers of } \mathrm{T}_{\text {reg }} \text { cells }\end{array}$ & $\begin{array}{c}{[46,47]} \\
{[46]} \\
{[4]} \\
{[46]} \\
{[64]} \\
{[47]} \\
{[57]} \\
{[4]} \\
{[74]} \\
{[75]}\end{array}$ \\
\hline
\end{tabular}

A summary of the hereto characterization of the natural killer (NK) cells, dendritic cells (DCs) and T lymphocytes in untreated AML patients. PB: peripheral blood; IDO: Indoleamine 2,3-dioxygenase; $\mathrm{mDC}$ : myeloid DC; pDC: plasmacytoid DC; NKT: natural killer T; $\mathrm{T}_{\text {reg }}$ : regulatory $\mathrm{T}$. 


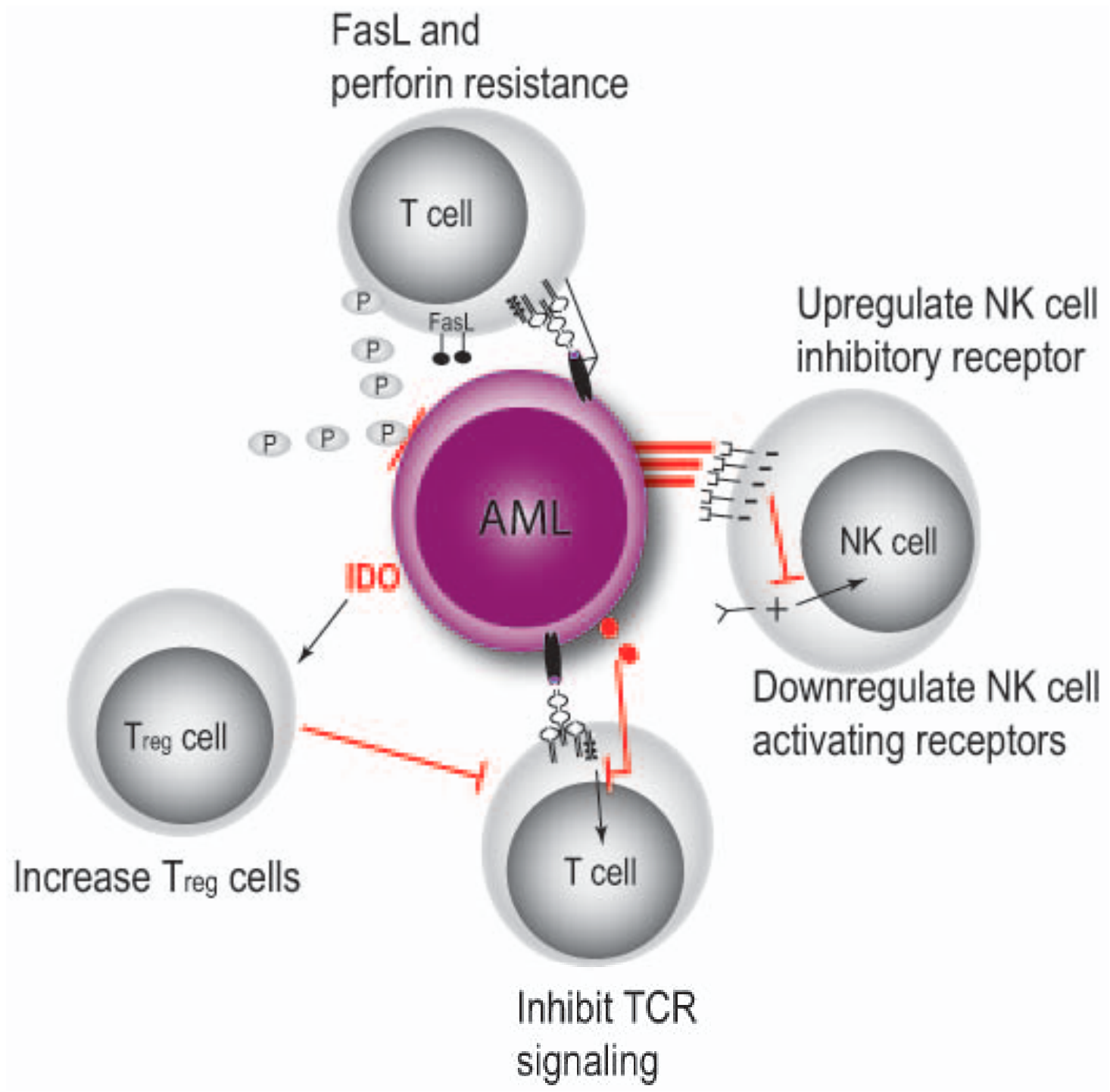

Fig. (1). The AML cell promoting immune dysfunctions.

Some of the immune dysfunctions described in AML are; i) the natural killer (NK) cells seem to display a more inhibitory than activating receptor phenotype, ii) the AML cells display more inhibitory than activating NK cell ligands, iii) the AML cell microenvironment inhibit T cell receptor (TCR) signaling and thus $\mathrm{T}$ cell activation, iv) increased expression of indoleamine 2,3-dioxygenase (IDO) correlates with increased numbers of regulatory $\mathrm{T}\left(\mathrm{T}_{\text {reg }}\right)$ cells, and v) AML cell resistance to perforin $(\mathrm{P})$ and FasL $(\mathrm{CD} 95 \mathrm{~L})$ mediated cell death.

system, and they are important in maintaining homeostasis and peripheral tolerance $[3,13,14]$. There are several reports of DC defects in cancer patients (reviewed in [15]). Abnormal frequencies as well as abnormal differentiation and/or maturation possibly caused by cancer derived soluble mediators, are among the dysfunctions described [15]. Immature DCs have been described to induce regulatory $\mathrm{T}$ cells inducing $\mathrm{T}$ cell anergy [16], and because AML cells themselves may be classified as malignancy derived from DC precursors [17], one might hypothesize the leukemic cells to behave as immature DCs (Fig. 2).

A number of studies concerning AML throw light on the generation of leukemic DCs in the context of immunotherapy (reviewed in [18]). There is to our knowledge only one study concerning the remaining non-leukemic DCs in AML; Mohty et al. [19] reported a quantitative imbalance in circulating blood myeloid DCs (mDCs) and plasmacytoid monocytes (pDCs) in $70 \%$ of the AML patients examined (Table 2). However, both subsets included leukemic cytogenetic features [19], and as pointed out recently by Panoskaltsis [17], the non-leukemic DC subset identification can be difficult because leukemic blasts may be misidentified as normal DCs due to the presence of DC-associated markers. Thus, these observations have to be interpreted with great care.

In patients with breast cancer the presence of $\mathrm{pDCs}$ $\left(\mathrm{CD} 123^{+} \mathrm{BDCA}^{+}\right)$, revealed by immunohistochemistry of the breast cancer tissue, suggested a disease-promoting activity of pDCs that was possibly caused by pDCs strong production of type I IFN [20]. It is not known whether similar mechanisms are operative in AML, but at least for T cells the release of hematopoietic growth factors may support disease progression (see below).

\section{T Lymphocytes: Normal Levels and Functional Status}

$\mathrm{T}$ lymphocytes are a heterogeneous population comprising cell subsets like cytokine-secreting $\mathrm{CD} 4^{+} \mathrm{T}$ helper $\left(\mathrm{T}_{\mathrm{H} 1}\right.$ or $\left.\mathrm{T}_{\mathrm{H} 2}\right)$ cells, cytotoxic killer $\mathrm{CD}^{+} \mathrm{T} \quad\left(\mathrm{T}_{\mathrm{C} 1}\right.$ or 
Table 3. Human NK Cells Surface Receptors, their Ligands and Signaling Type

\begin{tabular}{|c|c|c|}
\hline \multicolumn{3}{|c|}{ NK cells inhibitory receptors ${ }^{3}$} \\
\hline Receptor family & Receptor $^{1}$ & Known ligands ${ }^{2}$ \\
\hline $\mathrm{KIR}^{+}$ & KIR2DL1 (CD158a) $)^{+}$ & HLA-C group 2 \\
\hline $\mathrm{KIR}^{+}$ & $\begin{array}{l}\text { KIR2DL2/3 } \\
(\mathrm{CD} 158 \mathrm{~b})^{+}\end{array}$ & HLA-C group 1 \\
\hline KIR & KIR3DL1 & HLA-B alleles \\
\hline KIR & KIR3DL2 & HLA-A alleles \\
\hline LIR & LIR-1/IL T2 (CD85j) & HLA class I \\
\hline NKG2 & $\begin{array}{c}\text { NKG2A } \\
(\mathrm{CD} 94 / \mathrm{CD} 159 \mathrm{a})\end{array}$ & HLA-E \\
\hline KLR & KLRG1 & E/N/P-cadherin \\
\hline NKR & NKR-P1 (CD161) & LLT1 \\
\hline IGSF & Siglec-7 (CD328) & Sialic acid \\
\hline IGSF & Siglec-9 (CD329) & Sialic acid \\
\hline IGSF & IRp60 (CD300a) & Unknown \\
\hline \multicolumn{3}{|c|}{ NK cells activating receptors ${ }^{4}$} \\
\hline Receptor family & Receptor $^{1}$ & Known ligands ${ }^{2}$ \\
\hline KIR & KIR2DS & HLA class I \\
\hline KIR & KIR3DS & HLA class I \\
\hline NKG2 & NKG2C/E (CD94) & HLA-E \\
\hline NKG2* & NKG2D* & MICA/B*, ULBP* \\
\hline $\mathrm{NCR}^{*}$ & NKp30* & Unknown* \\
\hline $\mathrm{NCR}^{*}$ & NKp44/46* & Influenza HA \\
\hline $\mathrm{F} c \gamma \mathrm{R}$ & CD16 & IgG Fc region \\
\hline IGSF & 2B4 (CD244) & CD48 \\
\hline TNF-R & $\mathrm{CD} 27$ & $\mathrm{CD} 70$ \\
\hline $\mathrm{CD} 28$ & $\mathrm{CD} 28$ & CD80, CD86 \\
\hline $\mathrm{CD} 2$ & CD2 & LFA-3 (CD58) \\
\hline
\end{tabular}

After engagement of the NK cell receptor ${ }^{1}$ by the specific ligand ${ }^{2}$, the receptor exerts an inhibitory ${ }^{3}$ or activating ${ }^{4}$ signal to NK-mediated lysis of target cell $[166,167] .{ }^{+}$NK cell receptors upregulated in AML patients [10]. * Downregulated NK cell receptors and ligands in AML patients [12, 105]. KIR: Killer Cell Ig-Like Receptor; LIR: leukocyte Ig-like receptor; KLR: killer cell lectin-like receptor; IGSF: immunoglobulin superfamily; Fc $\gamma \mathrm{R}$ : Fc gamma receptor; TNF-R: tumor necrosis factor receptor; NCR: natural cytotoxicity receptor.

$\mathrm{T}_{\mathrm{C} 2}$ ), natural killer $\mathrm{T}(\mathrm{NKT})$ cells and regulatory $\mathrm{T}\left(\mathrm{T}_{\mathrm{reg}}\right)$ cells (Table 1) $[3,13,21]$. Altered ratios of $\mathrm{T}_{\mathrm{H} 1}$ versus $\mathrm{T}_{\mathrm{H} 2}$ or $\mathrm{T}_{\mathrm{C} 1}$ versus $\mathrm{T}_{\mathrm{C} 2}$ cells are observed in several malignancies [22-31]. However, a decreased total $\mathrm{T}$ cell number without such shifts is also reported in cancer patients [32, 33], as well as close to normal or increased $\mathrm{T}$ cell numbers $[34,35]$. The most probable explanation for this variation is that there are differences between malignancies and possibly also between individual cancer patients. Age and race-dependent differences may also contribute. Furthermore, an abnormal
CD4:CD8 ratio has been reported in certain malignancies [36-40]. This ratio can vary depending on the immunological compartment investigated: lymph node versus peripheral blood versus tumor-infiltrating lymphocytes [38, 40, 41]. Additionally, it is suggested that cancer patients have more memory and less naive $\mathrm{T}$ cells applicable among PBL or tumor infiltrating lymphocytes [42-45].

Only few reports regard the $\mathrm{T}$ lymphocyte subsets in patients with de novo AML. Vidriales and colleagues [4] reported normal frequencies of $\mathrm{CD}^{+} \mathrm{CD} 45 \mathrm{RA}^{+}$and $\mathrm{CD} 4^{+} \mathrm{CD} 29^{+}$cells in the PB but increased numbers of the cytotoxic $\mathrm{CD}^{+} \mathrm{CD}^{2} 7^{+}$subset among $\mathrm{CD} 8^{+}$cells [4]. A more recent report [46] outlined that the absolute numbers of $\mathrm{CD}^{+} \mathrm{CD}^{+}$and $\mathrm{CD}^{+} \mathrm{CD}^{-}$(putative $\mathrm{CD} 4^{+}$) $\mathrm{T}$ cells in whole blood of 13 patients with AML were similar to those of healthy controls. However, there was a tendency for higher numbers of $\mathrm{CD}^{+} \mathrm{T}$ cells in the patients and this was also reflected in lower CD4:CD8 ratios [46]. The close to normal CD4:CD8 ratios were also observed in our own recent studies [47]. Thus, no major quantitative $T$ cell defects have been described for patients with newly diagnosed AML.

Panoskaltsis et al. [46] measured the intracellular cytokine levels of circulating lymphocytes derived from AML patients. They did not find any significant changes in the IL4 , IL-10, IL-12 or IFN $\gamma$ levels for the cell subsets derived from patients compared with healthy individuals, suggesting normal $\mathrm{T}_{\mathrm{H} 1}$ and $\mathrm{T}_{\mathrm{H} 2}$ profiles. However, a nonsignificant trend towards higher absolute numbers and percentages of $\mathrm{CD}^{+}$ and $\mathrm{CD}^{-}$lymphocytes with detectable IL-10, IL-12 and IFN $\gamma$ was observed for the AML patients.

To further investigate whether $\mathrm{T}$ cells were qualitatively affected in AML patients, functional analysis of T lymphocytes after in vitro activation through the CD3/TCR complex and CD28 costimulatory molecule, within a microenvironment dominated by autologous AML blast population, was recently reported [47]. When these results were compared with samples from healthy controls on a per cell basis the IFN $\gamma$ production for the anti-CD3 plus anti-CD28 activated AML samples was not significantly different from the healthy controls, suggesting that at least IFN $\gamma$ responsiveness of $\mathrm{T}$ cells was not modified in the presence of the AML cells [47]. Thus, this last study did not detect any functional $\mathrm{T}$ cell defect either, supporting the findings of Panoskaltsis et al. [46].

NKT cells are a heterogeneous group of T lymphocytes expressing NK cell-associated receptors and $\alpha \beta \mathrm{T}$ cellreceptor (TCR) that are lipid or glycolipid antigen-CD1d restricted rather than antigen-MHC restricted [48]. In cancer patients NKT cells may be both reduced and increased in numbers and may also have impaired ability to release cytokines [49-52]. Additionally, NKT cell number and function has been linked to prognosis in some malignancies [53-56]. This may also be true in AML as circulating $\mathrm{V} \alpha 24^{+} \mathrm{NKT}$ cells are decreased in patients with progressive disease [57]. In contrast, increased $\mathrm{CD}^{+} \mathrm{CD} 56^{+} \mathrm{NKT}$ cells have been found in $\mathrm{PB}$ from AML patients, while normal levels were found in BM [4]. Thus disease-induced alterations may differ between NKT cell subsets.

Misoguchi et al. [58] were the first to suggest that immune dysfunction in cancer patients was due to an altered 


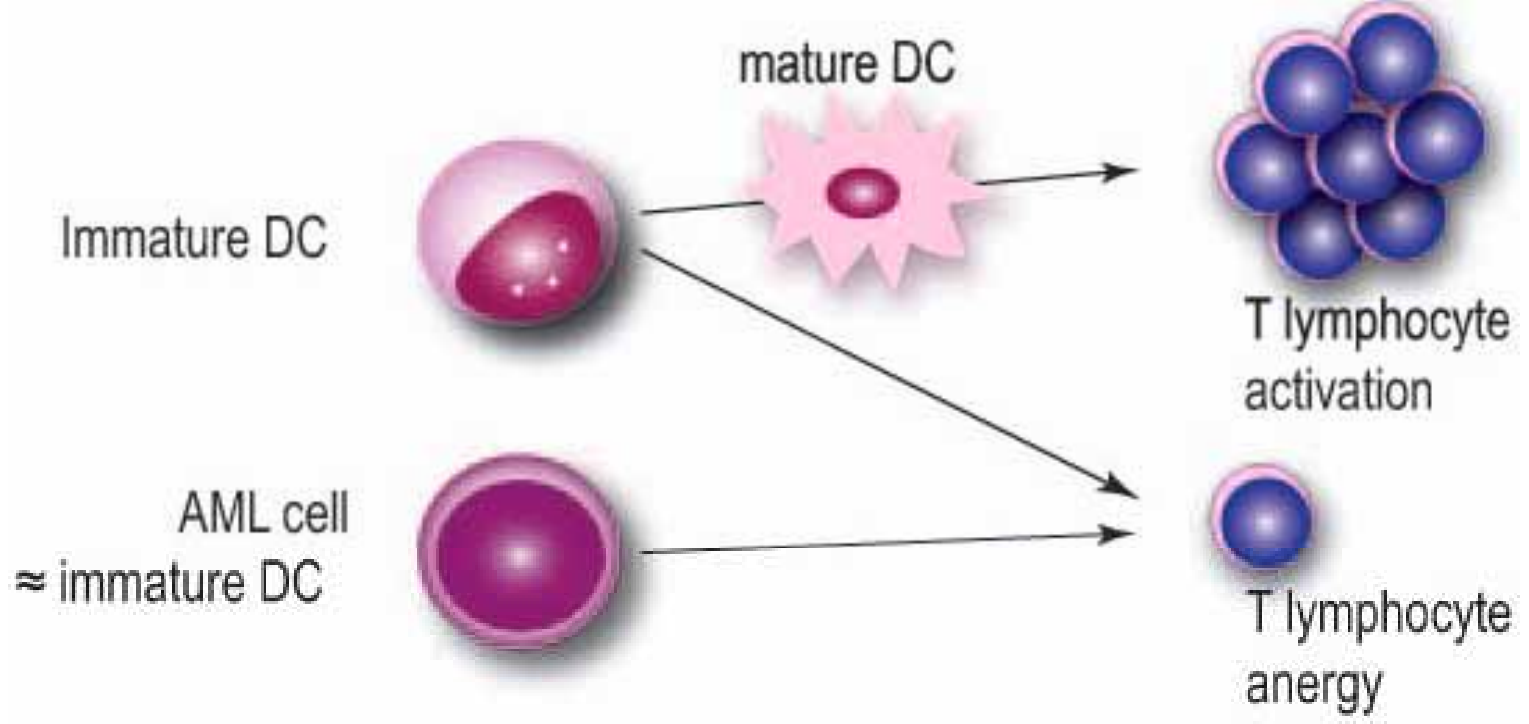

Fig. (2). Are AML cells behaving like immature DCs inducing T cell anergy?

Normally the immature dendritic cells (DCs) take up antigens, process the antigens while mature and finally induce T cell activation. However, immature DCs have been described to promote regulatory T cells inducing T cell anergy. Because AML cells themselves may be classified as malignancy derived from DC precursors one might hypothesize the leukemic cells to behave as immature DCs.

composition of the T-cell receptor signaling complex. Today, decreased expression of CD3- $\zeta$ (CD3- zeta) in T cells has been demonstrated in several malignancies [59-62]. Reduced $\mathrm{CD} 3-\zeta$ expression in tumor infiltrating lymphocytes even seems to be an independent prognostic factor for patients with oral carcinoma [63]. Buggins et al. [64] reported abnormal expression of $\mathrm{CD} 3-\zeta$ in $64 \%$ out of 46 myeloid leukemia patients examined (of which 11 were AML) and successful remission induction was associated with recovery of $\mathrm{CD} 3-\zeta$ expression. Also, the $\mathrm{CD} 3-\zeta$ associated protein tyrosine kinases (p56 $6^{\text {lck }}, \mathrm{p} 59^{\mathrm{fyn}}$, and ZAP-70) showed variable but often reduced expression in these patients [64]. Additionally, in a murine AML model [65] there were observed reduced responses (proliferation and IL-2 secretion) to mitogenic anti-CD3- $\varepsilon$ but not to PMA/ionomycin (which is TCR independent) as early as one week following the injection of leukemic cells, whereas loss of CD3- $\zeta$ protein expression together with intracellular signaling abnormalities (i.e. calcium mobilization and tyrosine kinase activity) were detected only in advanced disease (4 weeks after injection). It was also shown in vitro that leukemia-derived factor(s) stimulated splenic macrophages to secrete a second soluble factor(s) that caused the loss of CD3- $\zeta$ [65]. The AMLassociated $\mathrm{T}$ cell abnormalities are summarized in Table $\mathbf{2}$.

From the above mentioned studies it is difficult to reach a firm conclusion, partly due to the question of patient heterogeneity and the low number of patients in some of these studies. However, it is justified to conclude that there are no major quantitative defects for the total $\mathrm{T}$ cell population and most of the examined $\mathrm{T}$ cell subsets in untreated AML, but NKT cells may be an exception. Another exception is the increased frequency of $\mathrm{T}_{\text {reg }}$ cells (see below). The altered expression of the TCR signaling complex is probably the best example of a functional disturbance of $\mathrm{T}$ cells in AML (Fig. 1).

\section{$T_{\text {reg }}$ Cells: High Levels may Play a Critical Role in AML- Associated Immunosuppression}

$\mathrm{T}_{\text {reg }}$ cells (Table 1) control autoimmune $\mathrm{T}$ cell reactivity in the periphery and may also suppress immune responses against cancer cells (reviewed in [66]). An increased number of $\mathrm{T}_{\text {reg }}$ cells has been reported for patients with ovarian cancer, lung cancer, breast cancer, gastrointestinal malignancies and lymphoma [67-73]. In concordance with these findings, Wang et al. reported significantly higher proportions of $\mathrm{CD} 4{ }^{+} \mathrm{CD} 25^{\text {high }} \mathrm{T}_{\text {reg }}$ cells for PB and BM in AML patients compared with healthy controls [74]. These $\mathrm{CD} 4^{+} \mathrm{CD} 25^{\text {high }}$

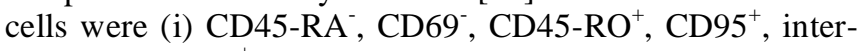
cellular CTLA-4 ${ }^{+}$; (ii) secreted low levels of TNF- $\alpha$ and IL10 and did not release IL-2, IL-4, IL-5 or IFN $\gamma$; and (iii) behaved as $\mathrm{T}_{\text {reg }}$ cells by inhibiting $\mathrm{CD} 4^{+} \mathrm{CD} 25^{-} \mathrm{T}$ cell proliferation and cytokine production during in vitro activation [74]. The AML cell expression of a key enzyme in the tryptophan metabolism; Indoleamine 2,3-dioxygenase (IDO), has been correlated with increased levels of circulating $\mathrm{CD} 4^{+} \mathrm{CD} 25^{+} \mathrm{FOXP} 3^{+} \mathrm{T}_{\text {reg }}$ cells in patients with AML at diagnosis [75]. Subsequent in vitro experiments indicated that AML cells induce T-cell anergy by directly converting $\mathrm{CD} 4^{+} \mathrm{CD} 25^{-} \mathrm{T}$ cells into $\mathrm{CD} 4^{+} \mathrm{CD} 25^{+} \mathrm{T}_{\text {reg }}$ cells through an IDO-dependent mechanism [75]. Thus, $\mathrm{CD}^{+} \mathrm{CD} 25^{+} \mathrm{T}_{\mathrm{reg}}$ cells are increased and possibly play a critical role in immunosuppression in AML (Fig. 1).

\section{LEUKEMIA ASSOCIATED ANTIGENS: A POSSIBLE ROLE IN DIAGNOSTIC CLASSIFICATION, PROG- NOSTIC EVALUATION OR IMMUNOTHERAPEU- TIC TARGETING?}

Several mutated or overexpressed proteins seem to be processed and presented to the immune system as tumor antigens leading to cellular and/or humoral responses [76]. One of the most extensively studied cancer-associated antigens is p53 [77], but more recent studies have demonstrated that 
Table 4. Leukemia Associated Antigens in Untreated AML Patients

\begin{tabular}{|c|c|c|}
\hline & Leukemia associated antigens & Ref. \\
\hline \hline Humoral recognized & WT-1, MPP-11, PASD1, RHAMM, MAZ, cyclin-B1, Rhamm-like protein & {$[81,84,85,87-89]$} \\
\hline $\mathrm{T}_{\mathrm{C}}$ cell recognized & WT-1, proteinase3, RHAMM, Bcl-2 & {$[91-93]$} \\
\hline
\end{tabular}

A brief summary of some of the antibody/B cells (humoral) and spontaneous cytotoxic $\mathrm{T}\left(\mathrm{T}_{\mathrm{C}}\right)$ cell recognized leukemia associated antigens (LAAs) described in AML patients. WT1: Wilms tumor gene product-1; MPP-11: the M-phase phosphoprotein 11; PASD-1: per ARNT SIM (PAS) domain containing 1; RHAMM: receptor for hyaluronan acid-mediated motility; MAZ: myc associated zinc finger; Bcl-2: B-cell CLL/lymphoma 2.

autoantibodies against a wide range of autoantigens can be detected in patients with malignant disorders [76, 78]. Zhang et al. investigated a group of 174 cancer patients for autoantibodies against 7 known antigens, each autoantibody could then be detected in $10-20 \%$ of the patients and approximately half of the patients had at least one autoantibody [76]. Cancer-associated humoral autoimmunity thus seems to be a common phenomenon, but autoimmune disease is uncommon in these patients [79].

The number of autoantibodies known to occur in AML patients is few compared to other malignancies. However, humoral responses against the following antigens have been detected at an increased frequency in AML patients compared with healthy controls (Table 4): Wilms tumor gene product (WT1) [80, 81], single-stranded DNA (ssDNA) [82], anticardiolipin antibodies (ACA) [83], the M-phase phosphoprotein 11 (MPP11) [84], receptor for hyaluronan acidmediated motility (RHAMM) [85], myc associated zinc finger (MAZ) [86], per ARNT SIM (PAS) domain containing 1 (PASD1) [87], cyclin B1 [88] and Rhamm-like protein [89]. Some of these autoantibodies have originally been detected in either disorders associated with tissue destruction such as systemic lupus erythematosus (SLE) (ssDNA) [82] or serious infections (ACA) [83], but tissue destruction alone (e.g. chemotherapy-induced cell damage) does not seem to be sufficient for development of humoral immune responses in AML [90].

Spontaneous $\mathrm{T}$ cell reactivity to leukemia associated antigens (LAAs) in AML patients with newly diagnosed disease include WT-1 peptides, proteinase3 peptides [91], RHAMM (CD168) peptides [92], and Bcl-2 peptides [93], all verified by ELISPOT and at least one additional method (e.g. tetramer staining) (Table 4). Vaccination with LAA peptides is therefore tried in the treatment of AML [94].

It is too early to conclude about the possible clinical importance of antileukemic immune reactivity in patients with untreated AML. Future studies should probably focus on antibody/T cell signatures as possible prognostic signatures, the effect of anticancer therapy on this reactivity and the development of clinical procedures to enhance this antileukemic reactivity.

THE CYTOKINE NETWORK: IMMUNOREGULATORY FACTORS ARE CONSTITUTIVELY RELEASED BY PRIMARY HUMAN AML CELLS

Numerous immunosuppressive factors like TGF- $\beta$, IL-10, vascular endothelial growth factor (VEGF), Fas-L and Fas have been detected in tumor microenvironments [95, 96]. Such tumor-derived factors can for instance induce apoptosis in $\mathrm{T}$ cells [96-99] or inhibit a Th1 response [100] and thereby contribute to local immunosuppression. Similar mechanisms seem to be operative in AML (Table 5). In addition to the above mentioned IDO-dependent $\mathrm{T}_{\text {reg }}$ cell induction [75], the AML microenvironment seems to be immunosuppressive by inhibiting $\mathrm{T}$ cell cytotoxic activity [101, 102]. AML culture supernatants have in addition shown a TGF- $\beta$, IL-10 and VEGF independent inhibition of T cell activation, $\mathrm{T}$ cell proliferation and Th1 cytokine production [102].

Chemokine release by primary AML cells appears in clusters, and the following three clusters could be identified based on correlations between chemokine levels: (i) CCL24/CXCL1/8, (ii) CCL5/CXCL9-10, and (iii) CCL13/17/22/24/CXCL5 [103]. Several of these chemokines (e.g. CCL5, CCL17, CXCL10) are $\mathrm{T}$ cell chemotactic chemokines [104]. It seems most likely that the final functional effect of this local chemokine release is recruitment and thereby enhancement of antitumor reactivity.

AML cell supernatants have been shown in experimental models to affect major signaling pathways involved in $\mathrm{T}$ cell activation and proliferation (summarized in Table 5); i) reduced nuclear translocation of the transcription factors NFATc and NF- $\mathrm{BB}$; ii) delayed activation of the mitogenactivated protein (MAP) kinase c-Jun $\mathrm{N}$-terminal kinase $1 / 2$ (JNK-1/2); iii) no phosphorylation of the cell cycle related proteins retinoblastoma protein $(\mathrm{pRb})$, cyclin-dependent kinase-6/4 (CDK-6/4) cyclin D and Rb family member $\mathrm{p} 130$; and iv) no induction of the transcription factor c-Myc, the cell cycle protein cyclin D3 and the Rb family member p107. Calcium mobilization, the MAP kinase extracellular signalregulated kinase-1/2 (ERK-1/2) and p38, as well as the signal transducer and activator of transcription protein-5 (STAT-5) remained unaffected [102]. Taken together these observations clearly demonstrate that AML-derived soluble mediators have extensive effects on the intracellular $\mathrm{T}$ cell signalling (Fig. 1).

\section{AML CELLS: IMMUNOLOGICAL ESCAPE PHENO- TYPE AND RESISTANCE TO IMMUNOLOGICAL MEDIATED CELL DEATH}

In addition to proposed immunosuppressive factors constitutively released by AML cells, an immune escape phenotype of AML cells has been suggested (see Table 5). We have already mentioned the NCR ${ }^{\text {dull }}$ NK lymphocyte phenotype that is most possibly induced by direct contact with the leukemic blasts [12] and the high expression of inhibitory over activating KIR ligands on the AML cells [11] (Fig. 1). Moreover, ligands for NK cell-activating receptors are expressed only at very low levels in leukemic cells in 80 percent of patients [105]. In vitro administration of differentiation-promoting drugs upregulate NK cell-activating receptor expression and enhances the susceptibility of AML cells to 
Table 5. AML Induced Suppression of Immune Cells

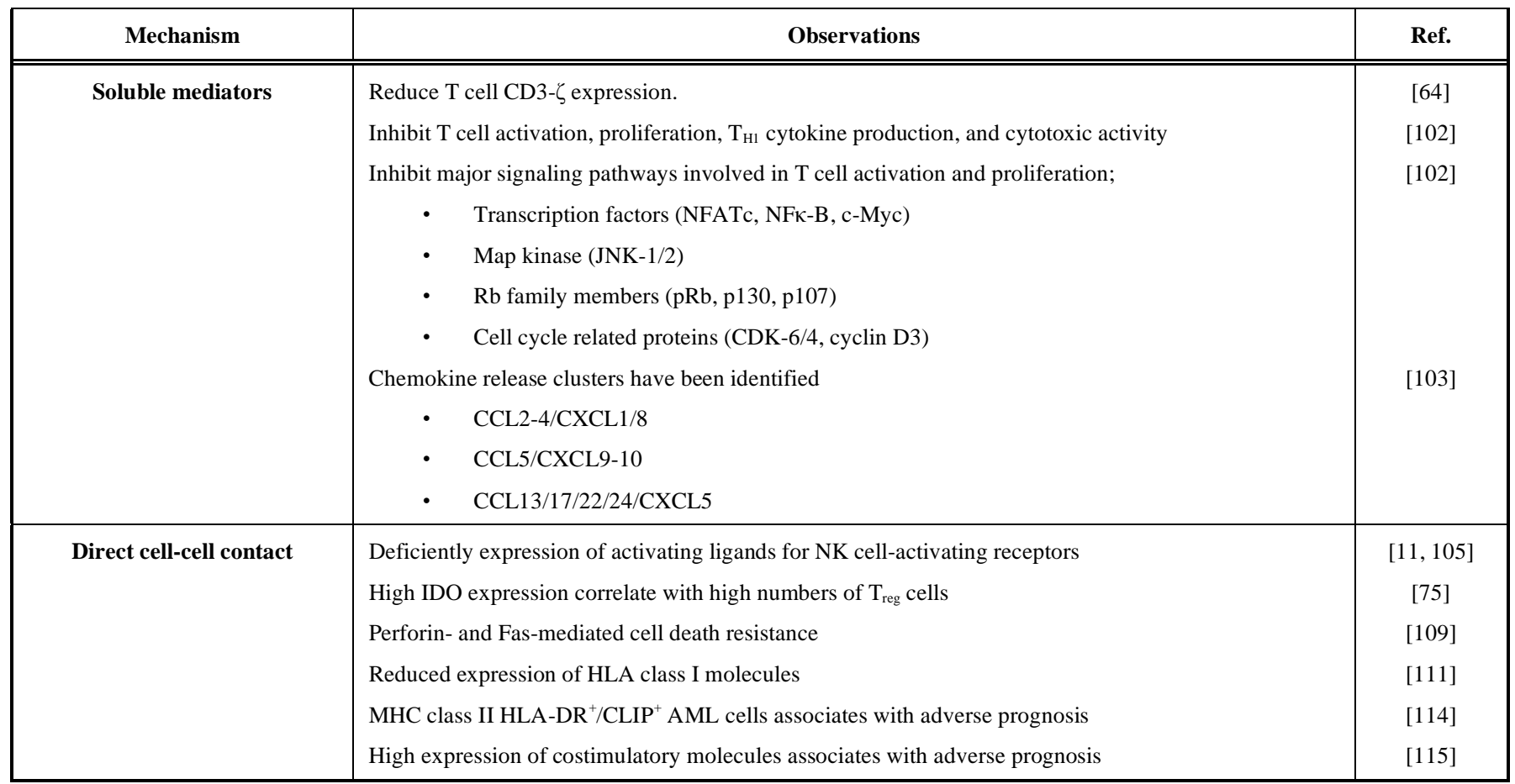

IDO: Indoleamine 2,3-dioxygenase, CLIP: class-II associated invariant chain peptide.

NK cell-mediated lysis $[105,106]$. Thus, the NK cell-escape phenotype alsocan be overcome, but differentiationpromoting drugs may also prevent NK cytotoxicity by downregulation of NK cell activating receptors [107].

The two major mechanisms by which immune effector cells exert their cellular cytotoxicity is through granule exocytosis and Fas (CD95) ligation [108]. Granzymes and perforin are the major components of the cytotoxic granules in both T and NK cells [108]. A perforin- and Fas-mediated cell death resistance has been suggested for AML cells [96, 109, 110] (Fig. 1), but due to the small numbers of patients included in these studies no firm conclusion can be made regarding the clinical significance.

The expression of the major histocompatibility complex (MHC) genome area class I and II is crucial for LAA presentation. HLA class I molecules are reduced in AML blasts compared to normal monocytes [111]. Myeloid progenitor cells seem to temporarily express HLA class II molecules during differentiation to granulocytes and macrophages [112]. Primary human AML cells also express HLA class II molecules $[113,114]$. A recent study outlines the importance of class-II associated invariant chain peptide (CLIP) expression and the HLA-DO:HLA-DM ratio for prediction of clinical outcome of AML patients [114]. Based on these findings the authors suggested that HLA-DR ${ }^{+} / \mathrm{CLIP}^{-}$AML cells were able to present leukemia-specific antigens and therby initiating an effective and long-lasting antitumor response, whereas this was not the case for $\mathrm{HLA}-\mathrm{DR}^{+} / \mathrm{CLIP}^{+}$AML cells [114].

Recently a study investigating the costimulatory expression profile of primary human AML cells concluded that i) the expression of costimulatory molecules in AML was very variable, ii) $\mathrm{CD}^{+} 6^{+}$AML subtypes were associated with an adverse prognosis, and iii) high expression of certain costimulatory molecules (e.g. CD80, CD86) also correlated with worse prognosis [115]. The negative effect of high CD86 (B7-2) expression has also been reported previously [116], whereas the results for CD80 (B7-1) expression are conflicting [111, 113, 115-117]. The association of adverse prognosis with high expression of certain costimulatory molecules, is contradictory to the hypothesis that high levels of costimulatory molecules are favorable for immunological recognition and destruction of AML cells and therefore would be expected to be associated with a good prognosis.

The costimulatory cytotoxic T-lymphocyte-associated antigen-4 (CTLA-4) is a negative regulator of T cell activation. Recently, CTLA-4 was reported constitutively expressed by $80 \%$ of AML samples tested [118, 119]. Blocking either PD-1L, CD80 or CTLA-4 in vivo prolonged the survival of naive mice engrafted with AML cells [120].

To conclude, additional studies are clearly needed to further elucidate the role of the $\mathrm{T}$ cell costimulatory or inhibitory molecules in AML to clarify whether these molecules have effects in immunoregulation, or whether high expression of these molecules is only a part of a functional AML cell phenotype associated with chemoresistance or a more aggressive disease.

\section{INTENSIVE AML CHEMOTHERAPY: EARLY IM- MUNOLOGICAL RECONSTITUTION IS A GOOD PROGNOSTIC FACTOR}

\section{Immune Function in AML Patients with Severe Chemo- therapy-Induced Cytopenia}

Cytotoxic antineoplastic therapy disrupts T cell homeostasis and is the primary contributor to the severe clinical immunodeficiency observed in AML patients [121]. The 
Table 6. Immune System in AML Patients with Chemotherapy-Induced Cytopenia

\begin{tabular}{|c|l|c|}
\hline Cell type & Abnormality & Ref. \\
\hline \hline NK cells & No studies & \\
\hline DCs & No studies & Circulating IL-7 responsive T cells \\
Most T cells express CD45RO, HLA-DR, CD25, CD69 & Reduced frequencies of clonogenic T cells & {$[125]$} \\
\hline T cells & $\begin{array}{l}\text { In vitro aCD3+aCD28 T cell proliferative response equal to healthy control } \\
\text { T cell directed pharmacological targeting may be possible }\end{array}$ & {$[130]$} \\
\hline B cells & Generally less than 10\% of the leukocytes & {$[135]$} \\
\hline
\end{tabular}

NK: natural killer cells; DCs: dendritic cells; aCD3: antibody against CD3; aCD28: antibody against CD28.

impact of the immune system for outcome after chemotherapy was recently elucidated by Behl et al. [122], finding that rapid absolute lymphocyte count recovery after induction chemotherapy predicts superior survival in AML.

In general, patients receiving chemotherapy for various malignant disorders seem to develop a $\mathrm{CD} 4^{+} \mathrm{T}$ lymphopenia together with high serum levels of the pleiotropic cytokine IL-7 [123, 124]. In contrast, AML patients with severe chemotherapy-induced leukopenia and $\mathrm{CD}^{+} \mathrm{T}$ lymphopenia, showed decreased IL-7 serum levels, and the detection of circulating IL-7-responsive T cells in these patients indicated that variations in systemic IL-7 levels are functionally important and may contribute to the $\mathrm{T}$ cell defect in lymphopenic AML patients [125]. Other studies have demonstrated that administration of recombinant IL-7 to humans could selectively increase total $\mathrm{CD}^{+}$and $\mathrm{CD} 8^{+} \mathrm{T}$ lymphocytes and decrease the percentage of $\mathrm{CD}^{+} \mathrm{T}_{\text {reg }}$ cells [126]. The possible clinical use of IL-7 therapy in AML has not been investigated.

For AML patients with chemotherapy-induced cytopenia most circulating leukocytes are $\mathrm{T}$ lymphocytes, whereas B lymphocytes and monocytes show a wide variation among patients but usually represent less than $10 \%$ of the leukocytes (Table 6) [127]. Most of the circulating $T$ cells in cancer patients with chemotherapy-induced cytopenia seem to express the activation markers HLA-DR as well as CD25 and CD69, and this is also true in human AML [128, 129]. Following chemotherapy there seems to be an absence of $\mathrm{CD}^{+}{ }^{+} \mathrm{CD} 45 \mathrm{RA}^{+} \mathrm{T}$ cells, all the remaining $\mathrm{CD} 4^{+} \mathrm{T}$ cells expressing the $\mathrm{CD}^{2} 5 \mathrm{RO}^{+}$isoform $[121,128]$.

There have also been some reports regarding qualitative/functional evaluation of $\mathrm{T}$ cells, these include the examination of cytokine release and cytokine responsiveness of in vitro expanded clonogenic T cells derived from AML patients with therapy-induced cytopenia [129-133]. These clonogenic cells constitute a minor population of circulating $\mathrm{T}$ cells including $\mathrm{CD}^{+}$and $\mathrm{CD}^{+}{ }^{+} \mathrm{TCR} \alpha \beta^{+}$cells [130], and the cells secrete a wide range of immunoregulatory cytokines [131]. The frequency of these clonogenic $\mathrm{T}$ cells is often reduced compared to healthy individuals [130].
Very few studies have included functional analysis of circulating $\mathrm{T}$ cells other than the clonogenic minority. However, there are studies of the proliferative responsivness of $\mathrm{T}$ cell derived from AML patients with severe leucopenia evaluated in a whole blood assay [127, 134]. In this assay activated $\mathrm{T}$ cells were found to have proliferative responsiveness equal to healthy controls in the presence of optimal stimulation with anti-CD3 plus anti-CD28, but responses were significantly reduced in the patient samples when using anti-CD3 stimulation only. Furthermore, the responses were significantly lower for ALL than for the AML patients [127].

More recently, we reported that the in vitro activated $\mathrm{T}$ cells in this whole blood assay show a broad cytokine release profile including high and significantly correlated release of IFN $\gamma$ and GM-CSF [135]. The anti-CD3 plus anti-CD28stimulated IFN $\gamma$ release, but not GM-CSF release, was significantly lower for AML patients than for healthy individuals. This difference is probably caused by combined qualitative and quantitative defects within the remaining $\mathrm{T}$ cell population in the AML patients [127, 134]. Additionally, higher IFN $\gamma$ and GM-CSF levels were significantly associated with older age, an observation clearly demonstrating that age therapeutic-dependent alterations have to be considered when clinical trials of immunotherapy are designed [135]. Significantly higher T cell proliferation and cytokine release were also observed when the novel drug PEP005 (a protein kinase $\mathrm{C}$ agonist) was added, thus indicating that pharmacological immunotargeting could be possible in these severely compromised patients [135].

\section{Immune Reconstitution after Conventional Intensive Chemotherapy: the Impact of Thymic Atrophy}

Effective immunological functions after chemotherapy and myeloablative therapy depend upon reconstitution of antigen specific $\mathrm{T}$ cells. For the recovery of $\mathrm{T}$ cells renewed thymopoiesis is crucial [136]. Thymus involution rapidly reduces its function to $<5 \%$ of its maximal capacity after puberty $[137,138]$. Therefore, when $\mathrm{T}$ cell levels are severely decreased after chemotherapy, the ability to regenerate the $\mathrm{T}$ cell repertoire is severely compromised and worsening occurs with increasing age [139]. Thus, the T cell re- 
generation can be divided into two different pathways mainly dependent upon age. Firstly, in young patients HSCs generate T cell committed HPCs (T-HPCs: CD $34^{+} \mathrm{CD}^{+} \mathrm{CD} 3^{-}$ ) in the $\mathrm{BM}$ that transmigrate to the thymus where the $\mathrm{T}$ HPCs down-regulate the CD34 antigen, up-regulate the expression of $\mathrm{T}$ cell receptors (TCRs) and CD3 antigen and finally differentiate into naive $\mathrm{CD}^{+}$and $\mathrm{CD}^{+} \mathrm{T}$ cells $[140$, 141]. Alternatively, adult patients with thymic atrophy regenerate the $\mathrm{T}$ cell compartment principally by antigen induced conversion of naive to memory $\mathrm{T}$ cells and subsequent expansion [141-143]. This implies that adults show a delay in peripheral $\mathrm{T}$ cell regeneration as well as increased incidence of opportunistic infections compared to younger individuals [144]. Among suggested approaches to treat such immunodeficiency states in adults are the use of sex-steroid ablation or androgen blockade to activate thymic regeneration which may lead to the reversal of age-related thymic atrophy [145-147]. However, fatal infections are uncommon after hematopoietic reconstitution, and only low- or nontoxic strategies to enhance immune reconstitution are therefore justified.

Effective immunological function after chemotherapy also depends upon reconstitution of antigen specific antibody production by B lymphocytes as well as NK cell reconstitution. In contrast to T cells, B cells and NK cells differentiate essentially in the bone marrow and thus depend upon an intact BM microenvironment. Additionally tissue-specific NK cell development (e.g. thymus) is hypothesized to exist [148], and thus thymic atrophy and age might also affect NK cell restoration.

\section{Complete Haematological Remission and Recovery of the Immunesystem}

Very few studies have examined the $\mathrm{T}$ cell system in AML patients after hematopoietic reconstitution. Longlasting $\mathrm{T}$ cell defects can occur after intensive chemotherapy for other malignancies, especially in adult patients [121]. One would expect similar defects to occur after AML therapy. However, as mentioned above, the abnormal CD3- $\zeta$ expression on $\mathrm{T}$ cells from AML patients was recovered when achieving remission [64]. Furthermore, low expression of the activating natural cytotoxicity receptors $\left(\mathrm{NCR}^{\text {dull }}\right)$ on NK cells (see above) in AML patients was completely or partially restored in patients achieving remission [12]. These studies suggest that the continued presence of leukemia cells are necessary for abnormal CD3- $\zeta$ expression on $\mathrm{T}$ cells and NCR down-regulation on NK cell.

\section{IMMUNE RECONSTITUTION AFTER AUTOLO- GOUS STEM CELL TRANSPLANTATION: INFLU- ENCED BY STEM CELL MOBILIZATION RE- GIMES?}

Similar to the significance of the immune system reconstitution after induction therapy [122], early lymphocyte recovery is a predictive factor for prolonged survival after autologous stem cell transplantation (auto-SCT) for AML patients [149].

The recirculation pattern of injected leukocyte subpopulations during the first 24 hours after auto-SCT of AML differs between leukocyte subsets [150]; i) the number of $\mathrm{CD}^{+}$ $\mathrm{T}$ lymphocytes increases during this period, ii) $\mathrm{CD}^{+} 6^{+} \mathrm{NK}$ cells decrease rapidly after auto-SCT and remain low throughout the observation period of 24 hours, and iii) $\mathrm{B}$ lymphocyte levels are also low during the first 24 hours [150].

The early reconstitution of the T lymphocyte system after both auto- and allo-SCT is mainly due to the peripheral expansion of mature $\mathrm{T}$ cells transferred with the graft [142, 151]. The recovery of polyclonal $\mathrm{T}$ lymphocytes occurs gradually, and complete reconstitution of humoral and cellular immunity may take more than one year [152]. Similar to the observations in patients only receiving intensive chemotherapy, there seems to be an absence of CD $4^{+} \mathrm{CD} 45 \mathrm{RA}^{+} \mathrm{T}$ cells early after auto-transplantation with a remaining population of $\mathrm{CD}^{+} \mathrm{CD} 45 \mathrm{RO}^{+}$circulating $\mathrm{T}$ lymphocytes [121, $128,153]$. One study has suggested that BM-resident memory $\mathrm{T}$ cells are resistant to both pretransplant chemotherapy and ex vivo pharmacological purging and thus may contribute to the immune reconstitution after auto-SCT [154].

G-CSF is the growth factor most commonly used for stem cell mobilization. T cells in PB after HSC mobilization with G-CSF have been analyzed: some studies indicate that G-CSF doubles the total number of circulating $\mathrm{T}$ cell without major changes in the fractions of various $\mathrm{T}$ cell subsets [141, 155]. However, other functional studies [156-158] indicate that G-CSF might affect the cytotoxic T cells by stimulating these lymphocytes to preferentially release type 2 cytokines (IL-4 and IL-10) rather than type I (IFN $\gamma$, TNF- $\alpha$, IL-2) upon activation. G-CSF may in addition increase the number of circulating $\mathrm{T}_{\text {reg }}$ cells [159].

\section{THE EARLY IMMUNE RECOVERY AFTER ALLO- GENEIC STEM CELL TRANSPLANTATION IS IM- PORTANT FOR SUCCESSFUL TRANSPLANT OUT- COME}

Allogeneic stem cell transplantation (allo-SCT) can be a curative treatment for younger AML patients. Bone marrow $(\mathrm{BM})$, cord blood (CB), and G-CSF-mobilized peripheral blood progenitor cell (PBPCs) can be used. A comparison of the cellular composition of leukapheresis products (LPs), CB allografts and BM allografts demonstrated that the composition of the graft lymphocytes differed considerably. T, B and NK cells were highest in LPs and lowest in CB allografts [141]. Also, early immune recovery is possibly enhanced following blood stem cell allografting compared with BM allografting; this is probably due to the large number of mature lymphocytes in blood stem cell allografts [160].

Recently, lymphocyte recovery at 3, 6 and 12 months after allo-SCT, was characterized for patients with various hematological malignancies, including AML [161]. In summary, this study revealed: $i$ ) a rapid $\mathrm{CD}^{+} 6^{+} \mathrm{NK}$ cell recovery at 3 months, ii) the $\mathrm{CD} 19^{+} \mathrm{B}$ cell recovery was slow as only $45 \%$ of patients recovered ${\mathrm{CD} 19^{+}}^{+}$cell counts above $50 \times 10^{6} / \mathrm{L}$ at 3 months, iii) an inverted CD4:CD8 ratio was observed during the first year, $i v$ ) the $\mathrm{CD} 4^{+}$helper $\mathrm{T}$ cell reconstitution at 3 months was associated with improved overall survival when using the cutoff value of $200 \times 10^{6} / \mathrm{L}$ $\mathrm{CD}^{+}$helper $\mathrm{T}$ cells, v) rapid $\mathrm{CD}^{+}$helper $\mathrm{T}$ cell recovery was also associated with a higher $\mathrm{CD} 4^{+}$helper $\mathrm{T}$ cell transplant dose and HLA-matched sibling donors, vi) an early $\mathrm{CD}^{+}$helper $\mathrm{T}$ cell recovery at 3 months correlated with a subsequent faster helper $\mathrm{T}$ cell recovery until 12 months but 
not with faster B cell recovery, and vii) rapid recovery of $\mathrm{CD}^{+}$helper $\mathrm{T}$ cells at 3 months was a favorable prognostic factor in terms of overall survival and non-relapse mortality [161]. In addition to the non-relapse mortality reduction the donor $\mathrm{T}$ cells are important for the graft-versus-leukemia (GvL) effect together with NK cells [162]. The general principles of GvL and GvHD are outlined in detail elsewhere [163].

Ruggeri et al. [162] have recently underlined the importance of KIR ligand mismatching, i.e. donor NK cell recognition of "missing self" on recipient targets, essential for triggering NK cell alloreactions beneficially for haplotypemismatched transplantation outcome [162]. However, this is not supported by other studies [164,165], and thus the effect of KIR ligand mismatching on the outcome of unrelated donor transplantation for AML patients, still remains obscure.

\section{CONCLUDING REMARKS}

Both the cellular innate and adaptive immune system in human AML patients differ from healthy individuals. AML patients are immunocompromized initially due to the disease and later due to intensive chemotherapy. We have included several examples of the importance of the immunological compartment and clinical significance in AML patients before, during and after treatment. However, future studies will be necessary to clarify the impact of the many immunological conditions for clinical relevance.

\section{ACKNOWLEDGEMENTS}

This work was supported by the Norwegian Cancer Society.

\section{REFERENCES}

[1] Smith M, Barnett M, Bassan R, Gatta G, Tondini C, Kern W. Adult acute myeloid leukaemia. Crit Rev Oncol Hematol 2004; 50: 197222.

[2] Farag SS, Caligiuri MA. Human natural killer cell development and biology. Blood Rev 2006; 20: 123-37.

[3] Delves PJ, Roitt IM. The immune system. First of two parts. N Engl J Med 2000; 343: 37-49.

[4] Vidriales MB, Orfao A, Lopez-Berges MC, Gonzalez M, Hernandez JM, Ciudad J, et al. Lymphoid subsets in acute myeloid leukemias: increased number of cells with NK phenotype and normal Tcell distribution. Ann Hematol 1993; 67: 217-22.

[5] Costello RT, Sivori S, Marcenaro E, Lafage-Pochitaloff M, Mozziconacci MJ, Reviron D, et al. Defective expression and function of natural killer cell-triggering receptors in patients with acute myeloid leukemia. Blood 2002; 99: 3661-7.

[6] Pierson BA, Miller JS. CD56+bright and CD56+dim natural killer cells in patients with chronic myelogenous leukemia progressively decrease in number, respond less to stimuli that recruit clonogenic natural killer cells, and exhibit decreased proliferation on a per cell basis. Blood 1996; 88: 2279-87.

[7] Sibbitt WL, Jr, Bankhurst, AD, Jumonville AJ, Saiki JH, Saiers JH, Doberneck RC. Defects in natural killer cell activity and interferon response in human lung carcinoma and malignant melanoma. Cancer Res 1984; 44: 852-6.

[8] Epling-Burnette PK, Bai F, Painter JS, Rollison DE, Salih HR, Krusch M, et al. Reduced natural killer (NK) function associated with high-risk myelodysplastic syndrome (MDS) and reduced expression of activating NK receptors. Blood 2007; 109: 4816-24.

[9] Richards JO, Chang X, Blaser BW, Caligiuri MA, Zheng P, Liu Y. Tumor growth impedes natural-killer-cell maturation in the bone marrow. Blood 2006; 108: 246-52.

[10] Verheyden S, Bernier M, Demanet C. Identification of natural killer cell receptor phenotypes associated with leukemia. Leukemia 2004; 18: 2002-7.
[11] Verheyden S, Demanet C. Susceptibility to myeloid and lymphoid leukemia is mediated by distinct inhibitory KIR-HLA ligand interactions. Leukemia 2006; 20: 1437-8.

[12] Fauriat C, Just-Landi S, Mallet F, Arnoulet C, Sainty D, Olive D, et al. Deficient expression of NCR in NK cells from acute myeloid leukemia: Evolution during leukemia treatment and impact of leukemia cells in NCRdull phenotype induction. Blood 2007; 109: 323-30.

[13] Delves PJ, Roitt IM. The immune system. Second of two parts. N Engl J Med 2000; 343: 108-1

[14] Fitzgerald-Bocarsly P, Feng D. The role of type I interferon production by dendritic cells in host defense. Biochimie 2007.

[15] Pinzon-Charry A, Maxwell T, Lopez JA. Dendritic cell dysfunction in cancer: a mechanism for immunosuppression. Immunol Cell Biol 2005; 83: 451-61.

[16] Ghiringhelli F, Puig PE, Roux S, Parcellier A, Schmitt E, Solary E, et al. Tumor cells convert immature myeloid dendritic cells into TGF-beta-secreting cells inducing CD4+CD25+ regulatory T cell proliferation. J Exp Med 2005; 202: 919-29.

[17] Panoskaltsis N. Dendritic cells in MDS and AML--cause, effect or solution to the immune pathogenesis of disease? Leukemia 2005; 19: 354-7.

[18] Schmitt A, Hus I, Schmitt M. Dendritic cell vaccines for leukemia patients. Expert Rev Anticancer Ther 2007; 7: 275-83.

[19] Mohty M, Jarrossay D, Lafage-Pochitaloff M, Zandotti C, Briere F, de Lamballeri XN, et al. Circulating blood dendritic cells from myeloid leukemia patients display quantitative and cytogenetic abnormalities as well as functional impairment. Blood 2001; 98: 3750-6.

[20] Bogdan C. Immunoregulatory and antimicrobial activities of myeloid cells. Eur J Immunol 2007; 37: 303-5.

[21] Seder RA, Ahmed R. Similarities and differences in CD4+ and CD8+ effector and memory T cell generation. Nat Immunol 2003; 4: 835-42.

[22] Ito N, Nakamura H, Tanaka Y, Ohgi S. Lung carcinoma: analysis of T helper type 1 and 2 cells and T cytotoxic type 1 and 2 cells by intracellular cytokine detection with flow cytometry. Cancer 1999; 85: 2359-67.

[23] Pellegrini P, Berghella AM, Del Beato T, Cicia S, Adorno D, Casciani CU. Disregulation in TH1 and TH2 subsets of CD4+ T cells in peripheral blood of colorectal cancer patients and involvement in cancer establishment and progression. Cancer Immunol Immunother 1996; 42: 1-8.

[24] Angevin E, Kremer F, Gaudin C, Hercend T, Triebel F. Analysis of $\mathrm{T}$-cell immune response in renal cell carcinoma: polarization to type 1-like differentiation pattern, clonal T-cell expansion and tumor-specific cytotoxicity. Int J Cancer 1997; 72: 431-40.

[25] Sato M, Goto S, Kaneko R, Ito M, Sato S, Takeuchi S. Impaired production of Th1 cytokines and increased frequency of Th2 subsets in PBMC from advanced cancer patients. Anticancer Res 1998; 18: 3951-5.

[26] Goto S, Sato M, Kaneko R, Itoh M, Sato S, Takeuchi S. Analysis of Th1 and Th2 cytokine production by peripheral blood mononuclear cells as a parameter of immunological dysfunction in advanced cancer patients. Cancer Immunol Immunother 1999; 48: 435-42.

[27] Tabata T, Hazama S, Yoshino S, Oka M. Th2 subset dominance among peripheral blood $\mathrm{T}$ lymphocytes in patients with digestive cancers. Am J Surg 1999; 177: 203-8.

[28] Zhang XL, Komada Y, Chipeta J, Li QS, Inaba H, Azuma E, et al. Intracellular cytokine profile of $\mathrm{T}$ cells from children with acute lymphoblastic leukemia. Cancer Immunol Immunother 2000; 49: 165-72.

[29] Ogawara H, Handa H, Yamazaki T, Toda T, Yoshida K, Nishimoto $\mathrm{N}$, et al. High Th1/Th2 ratio in patients with multiple myeloma. Leuk Res 2005; 29: 135-40.

[30] Luczynski W, Stasiak-Barmuta A, Krawczuk-Rybak M, Malinowska I. Assessment of selected co-stimulatory, adhesion and activatory molecules and cytokines of $\operatorname{Th}(1) / \mathrm{Th}(2)$ balance in acute lymphoblastic leukemia in children. Arch Immunol Ther Exp (Warsz) 2005; 53: 357-63.

[31] Reuben JM, Lee BN, Johnson H, Fritsche H, Kantarjian HM, Talpaz M. Restoration of Th1 cytokine synthesis by T cells of patients with chronic myelogenous leukemia in cytogenetic and hematologic remission with interferon-alpha. Clin Cancer Res 2000; 6: 1671-7. 
[32] Campbell MJ, Scott J, Maecker HT, Park JW, Esserman LJ. Immune dysfunction and micrometastases in women with breast cancer. Breast Cancer Res Treat 2005; 91: 163-71.

[33] Kuss I, Hathaway B, Ferris RL, Gooding W, Whiteside TL. Imbalance in absolute counts of T lymphocyte subsets in patients with head and neck cancer and its relation to disease. Adv Otorhinolaryngol 2005; 62: 161-72.

[34] Mellstedt H, Choudhury A. T and B cells in B-chronic lymphocytic leukaemia: Faust, Mephistopheles and the pact with the Devil. Cancer Immunol Immunother 2006; 55: 210-20.

[35] Isoda A, Yokohama A, Matsushima T, Tsukamoto N, Nojima Y, Karasawa M. The naive T-lymphocyte compartment is well preserved in patients with chronic myelogenous leukaemia in chronic phase. Br J Haematol 2002; 119: 949-55.

[36] Koike M, Sekigawa I, Okada M, Matsumoto M, Iida N, Hashimoto $\mathrm{H}$, et al. Relationship between $\mathrm{CD} 4(+) / \mathrm{CD} 8(+) \mathrm{T}$ cell ratio and $\mathrm{T}$ cell activation in multiple myeloma: reference to IL-16. Leuk Res 2002; 26: 705-11.

[37] Cartei G, Sala PG, Sanzari M, Ceschia V, Clocchiatti L, Sibau A, et al. Reduced lymphocyte subpopulations in patients with advanced or disseminated melanoma. J Am Acad Dermatol 1993; 28: 738-44.

[38] Snyderman CH, Heo DS, Johnson JT, Amico FD, Barnes L, Whiteside TL, Functional and phenotypic analysis of lymphocytes in head and neck cancer. Arch Otolaryngol Head Neck Surg 1991; 117: 899-905.

[39] Kaver I, Pecht M, Trainin N, Greenstein A, Braf Z. T lymphocyte subsets and function in the peripheral blood of patients with urological cancer. Oncology 1992; 49: 108-13.

[40] Redoglia V, Boccadoro M, Battaglio S, Dianzani U, Massaia M, Pileri A. Multiple myeloma: altered CD4/CD8 ratio in bone marrow. Haematologica 1990; 75: 129-31.

[41] Viale M, Ferrini S, Serrano S, Serrano D, Ardizzoni A, Nicolin A. Peripheral blood and tumor infiltrating lymphocytes in non-small cell lung cancer: analysis at the population and clonal level. Tumori 1990; 76: 488-94.

[42] Hueman MT, Stojadinovic A, Storrer CE, Dehqanzada ZA, Gurney JM, Shriver CD, et al. Analysis of naive and memory CD4 and CD8 $\mathrm{T}$ cell populations in breast cancer patients receiving a HER2/neu peptide (E75) and GM-CSF vaccine. Cancer Immunol Immunother 2006.

[43] Tsukishiro T, Donnenberg AD, Whiteside TL. Rapid turnover of the CD8(+)CD28(-) T-cell subset of effector cells in the circulation of patients with head and neck cancer. Cancer Immunol Immunother 2003; 52: 599-607.

[44] Atanackovic D, Block A, de Weerth A, Faltz C, Hossfeld DK, Hegewisch-Becker S. Characterization of effusion-infiltrating T cells: benign versus malignant effusions. Clin Cancer Res 2004; 10: 2600-8.

[45] Prado-Garcia H, Aguilar-Cazares D, Flores-Vergara H, Mandoki JJ, Lopez-Gonzalez JS. Effector, memory and naive CD8+ T cells in peripheral blood and pleural effusion from lung adenocarcinoma patients. Lung Cancer 2005; 47: 361-71.

[46] Panoskaltsis N, Reid CD, Knight SC. Quantification and cytokine production of circulating lymphoid and myeloid cells in acute myelogenous leukaemia. Leukemia 2003; 17: 716-30.

[47] Ersvaer E, Hampson P, Wendelbo O, Lord JM, Gjertsen BT, Bruserud O. Circulating T cells in patients with untreated acute myelogenous leukemia are heterogeneous and can be activated through the CD3/TCR complex. Hematology 2007; 12: 199-207.

[48] Sandberg JK, Ljunggren HG. Development and function of CD1drestricted NKT cells: influence of sphingolipids, SAP and sex. Trends Immunol 2005; 26: 347-9.

[49] Tahir SM, Cheng O, Shaulov A, Koezuka Y, Bubley GJ, Wilson $\mathrm{SB}$, et al. Loss of IFN-gamma production by invariant NK T cells in advanced cancer. J Immunol 2001; 167: 4046-50.

[50] Kawano T, Nakayama T, Kamada N, Kaneko Y, Harada M, Ogura $\mathrm{N}$, et al. Antitumor cytotoxicity mediated by ligand-activated human V alpha24 NKT cells. Cancer Res 1999; 59: 5102-5.

[51] Atanackovic D, Panse J, Schafhausen P, Faltz C, Bartels K, Boeters $\mathrm{I}$, et al. Peripheral T cells of patients with B cell non-Hodgkin's lymphoma show a shift in their memory status. Leuk Res 2005; 29: 1019-27.

[52] Fujii S, Shimizu K, Klimek V, Geller MD, Nimer SD, Dhodapkar MV. Severe and selective deficiency of interferon-gammaproducing invariant natural killer $\mathrm{T}$ cells in patients with myelodysplastic syndromes. Br J Haematol 2003; 122: 617-22.
[53] Dhodapkar MV, Geller MD, Chang DH, Shimizu K, Fujii S, Dhodapkar KM, et al. A reversible defect in natural killer T cell function characterizes the progression of premalignant to malignant multiple myeloma. J Exp Med 2003; 197: 1667-76.

[54] Molling JW, Kolgen W, van der Vliet HJ, Boomsma MF, Kruizenga H, Smorenburg $\mathrm{CH}$, et al. Peripheral blood IFN-gammasecreting Valpha24+Vbeta11+ NKT cell numbers are decreased in cancer patients independent of tumor type or tumor load. Int J Cancer 2005; 116: 87-93.

[55] van der Vliet HJ, Molling JW, Nishi N, Masterson AJ, Kolgen W, Porcelli SA, et al. Polarization of Valpha24+ Vbeta11+ natural killer $\mathrm{T}$ cells of healthy volunteers and cancer patients using alphagalactosylceramide-loaded and environmentally instructed dendritic cells. Cancer Res 2003; 63: 4101-6.

[56] Shimizu K, Hidaka M, Kadowaki N, Makita N, Konishi N, Fujimoto K, et al. Evaluation of the function of human invariant NKT cells from cancer patients using alpha-galactosylceramide-loaded murine dendritic cells. J Immunol 2006; 177: 3484-92.

[57] Yoneda K, Morii T, Nieda M, Tsukaguchi N, Amano I, Tanaka H, et al. The peripheral blood Valpha24+ NKT cell numbers decrease in patients with haematopoietic malignancy. Leuk Res 2005; 29: 147-52.

[58] Mizoguchi H, O'Shea JJ, Longo DL, Loeffler CM, McVicar DW, Ochoa AC. Alterations in signal transduction molecules in T lymphocytes from tumor-bearing mice. Science 1992; 258: 1795-8.

[59] Finke JH, Zea AH, Stanley J, Longo DL, Mizoguchi H, Tubbs RR, et al. Loss of T-cell receptor zeta chain and p56lck in T-cells infiltrating human renal cell carcinoma. Cancer Res 1993; 53: 5613-6.

[60] Matsuda M, Petersson M, Lenkei R, Taupin JL, Magnusson I, Mellstedt $\mathrm{H}$, et al. Alterations in the signal-transducing molecules of T cells and NK cells in colorectal tumor-infiltrating, gut mucosal and peripheral lymphocytes: correlation with the stage of the disease. Int J Cancer 1995; 61: 765-72.

[61] Renner C, Ohnesorge S, Held G, Bauer S, Jung W, Pfitzenmeier $\mathrm{JP}$, et al. T cells from patients with Hodgkin's disease have a defective T-cell receptor zeta chain expression that is reversible by Tcell stimulation with CD3 and CD28. Blood 1996; 88: 236-41.

[62] Rossi E, Matutes E, Morilla R, Owusu-Ankomah K, Heffernan AM, Catovsky D. Zeta chain and CD28 are poorly expressed on T lymphocytes from chronic lymphocytic leukemia. Leukemia 1996; 10: 494-7.

[63] Reichert TE, Day R, Wagner EM, Whiteside TL. Absent or low expression of the zeta chain in $\mathrm{T}$ cells at the tumor site correlates with poor survival in patients with oral carcinoma. Cancer Res 1998; 58: 5344-7.

[64] Buggins AG, Hirst WJ, Pagliuca A, Mufti GJ. Variable expression of CD3-zeta and associated protein tyrosine kinases in lymphocytes from patients with myeloid malignancies. Br J Haematol 1998; 100: 784-92.

[65] Hirst W, Buggins A, Mufti G. Central role of leukemia-derived factors in the development of leukemia-associated immune dysfunction. Hematol J 2001; 2: 2-17.

[66] Zou W. Regulatory T cells, tumour immunity and immunotherapy. Nat Rev Immunol 2006; 6: 295-307.

[67] Wolf AM, Wolf D, Steurer M, Gastl G, Gunsilius E, GrubeckLoebenstein B. Increase of regulatory $\mathrm{T}$ cells in the peripheral blood of cancer patients. Clin Cancer Res 2003; 9: 606-12.

[68] Woo EY, Chu CS, Goletz TJ, Schlienger K, Yeh H, Coukos G, et al. Regulatory CD4(+)CD25(+) $\mathrm{T}$ cells in tumors from patients with early-stage non-small cell lung cancer and late-stage ovarian cancer. Cancer Res 2001; 61: 4766-72.

[69] Ichihara F, Kono K, Takahashi A, Kawaida H, Sugai H, Fujii H. Increased populations of regulatory $\mathrm{T}$ cells in peripheral blood and tumor-infiltrating lymphocytes in patients with gastric and esophageal cancers. Clin Cancer Res 2003; 9: 4404-8.

[70] Liyanage UK, Moore TT, Joo HG, Tanaka Y, Herrmann V, Doherty G, et al. Prevalence of regulatory T cells is increased in peripheral blood and tumor microenvironment of patients with pancreas or breast adenocarcinoma. J Immunol 2002; 169: 2756-61.

[71] Woo EY, Yeh H, Chu CS, Schlienger K, Carroll RG, Riley JL, et $a l$. Cutting edge: Regulatory $\mathrm{T}$ cells from lung cancer patients directly inhibit autologous T cell proliferation. J Immunol 2002; 168: 4272-6.

[72] Marshall NA, Christie LE, Munro LR, Culligan DJ, Johnston PW, Barker RN, et al. Immunosuppressive regulatory $\mathrm{T}$ cells are abun- 
dant in the reactive lymphocytes of Hodgkin lymphoma. Blood 2004; 103: 1755-62.

[73] Sasada T, Kimura M,Yoshida Y, Kanai M, Takabayashi A. CD4+CD25+ regulatory $\mathrm{T}$ cells in patients with gastrointestinal malignancies: possible involvement of regulatory $\mathrm{T}$ cells in disease progression. Cancer 2003; 98: 1089-99.

[74] Wang X, Zheng J, Liu J, Yao J, He Y, Li X, et al. Increased population of CD4(+)CD25(high), regulatory $\mathrm{T}$ cells with their higher apoptotic and proliferating status in peripheral blood of acute myeloid leukemia patients. Eur J Haematol 2005; 75: 468-76.

[75] Curti A, Pandolfi S, Valzasina B, Aluigi M, Isidori A, Ferri E, et al. Modulation of tryptophan catabolism by human leukemic cells results in the conversion of CD25- into CD25+ T regulatory cells. Blood 2007; 109: 2871-7.

[76] Zhang JY, Casiano CA, Peng XX, Koziol JA, Chan EK, Tan EM. Enhancement of antibody detection in cancer using panel of recombinant tumor-associated antigens. Cancer Epidemiol Biomarkers Prev 2003; 12: 136-43.

[77] Soussi T. p53 Antibodies in the sera of patients with various types of cancer: a review. Cancer Res 2000; 60: 1777-88.

[78] Koziol JA, Zhang JY, Casiano CA, Peng XX, Shi FD, Feng AC, et al. Recursive partitioning as an approach to selection of immune markers for tumor diagnosis. Clin Cancer Res 2003; 9: 5120-6.

[79] Vedeler CA, Antoine JC, Giometto B, Graus F, Grisold W, Hart IK, et al. Management of paraneoplastic neurological syndromes: report of an EFNS Task Force. Eur J Neurol 2006; 13: 682-90.

[80] Wu F, Oka Y, Tsuboi A, Elisseeva, Ogata K, Nakajima H, et al. Th1-biased humoral immune responses against Wilms tumor gene WT1 product in the patients with hematopoietic malignancies. Leukemia 2005; 19: 268-74.

[81] Elisseeva OA, Oka Y, Tsuboi A, Ogata K, Wu F, Kim EH, et al. Humoral immune responses against Wilms tumor gene WT1 product in patients with hematopoietic malignancies. Blood 2002; 99 : 3272-9.

[82] Kostiala AA, Gripenberg M, Elonen E, Gripenberg G, Kostiala I. Follow-up of antibodies against single-stranded DNA in patients with haematological malignancies. Clin Exp Immunol 1985; 61: 15-23.

[83] Stasi R, Stipa E, Masi M, Oliva F, Sciarra A, Perrotti A, et al. Antiphospholipid antibodies: prevalence, clinical significance and correlation to cytokine levels in acute myeloid leukemia and nonHodgkin's lymphoma. Thromb Haemost 1993; 70: 568-72.

[84] Greiner J, Ringhoffer M, Taniguchi M, Hauser T, Schmitt A, Dohner $\mathrm{H}$, et al. Characterization of several leukemia-associated antigens inducing humoral immune responses in acute and chronic myeloid leukemia. Int J Cancer 2003; 106: 224-31

[85] Greiner J, Ringhoffer M, Taniguchi M, Schmitt A, Kirchner D, Krahn G, et al. Receptor for hyaluronan acid-mediated motility (RHAMM) is a new immunogenic leukemia-associated antigen in acute and chronic myeloid leukemia. Exp Hematol 2002; 30: 102935 .

[86] Greiner J, Ringhoffer M, Simikopinko O, Szmaragowska A, Huebsch S, Maurer U, et al. Simultaneous expression of different immunogenic antigens in acute myeloid leukemia. Exp Hematol 2000; 28: 1413-22.

[87] Guinn BA, Bland EA, Lodi UA, Liggins AP, Tobal K, Petters S, et al. Humoral detection of leukaemia-associated antigens in presentation acute myeloid leukaemia. Biochem Biophys Res Commun 2005; 335: 1293-304.

[88] Ersvaer E, Zhang JY, Mc Cormack E, Olsnes AM, Anensen N, Tan $\mathrm{EM}$, et al. Cyclin B1 is commonly expressed in the cytoplasm of primary human acute myelogenous leukemia cells and serves as a leukemia-associated antigen associated with autoantibody response in a subset of patients. European Journal of Haematology 2007; In press.

[89] Chen G, Zhang W, Cao X, Li F, Liu X, Yao L. Serological identification of immunogenic antigens in acute monocytic leukemia. Leuk Res 2005; 29: 503-9.

[90] Ersvaer E, Bertelsen LT, Espenes LC, Bredholt T, Boe SO, Iversen $\mathrm{BM}$, et al. Characterization of ribosomal $\mathrm{P}$ autoantibodies in relation to cell destruction and autoimmune disease. Scand J Immunol 2004; 60: 189-98.

[91] Scheibenbogen C, Letsch A, Thiel E, Schmittel A, Mailaender V, Baerwolf $\mathrm{S}$, et al. CD8 T-cell responses to Wilms tumor gene product WT1 and proteinase 3 in patients with acute myeloid leukemia. Blood 2002; 100: 2132-7.
[92] Greiner J, Li L, Ringhoffer M, Barth TF, Giannopoulos K, Guillaume $\mathrm{P}$, et al. Identification and characterization of epitopes of the receptor for hyaluronic acid-mediated motility (RHAMM/CD168) recognized by $\mathrm{CD} 8+\mathrm{T}$ cells of HLA-A2-positive patients with acute myeloid leukemia. Blood 2005; 106: 938-45.

[93] Andersen MH, Svane IM, Kvistborg P, Nielsen OJ, Balslev E, Reker S, et al. Immunogenicity of Bcl-2 in patients with cancer. Blood 2005; 105: 728-34.

[94] Greiner J, Dohner H, Schmitt M. Cancer vaccines for patients with acute myeloid leukemia--definition of leukemia-associated antigens and current clinical protocols targeting these antigens. Haematologica 2006; 91: 1653-61.

[95] Chouaib S, Asselin-Paturel C, Mami-Chouaib F, Caignard A, Blay YJ. The host-tumor immune conflict: from immunosuppression to resistance and destruction. Immunol Today 1997; 18: 493-7.

[96] Bruserud O, Ulvestad E. Soluble Fas/Apo-1 (CD95) levels during $\mathrm{T}$ cell activation in the presence of acute myelogenous leukemia accessory cells; contributions from local release and variations in systemic levels. Cancer Immunol Immunother 2000; 49: 377-87.

[97] Rabinowich H, Reichert TE, Kashii Y, Gastman BR, Bell MC, Whiteside TL. Lymphocyte apoptosis induced by Fas ligand- expressing ovarian carcinoma cells. Implications for altered expression of T cell receptor in tumor-associated lymphocytes. J Clin Invest 1998; 101: 2579-88.

[98] Gastman BR, Yin XM, Johnson DE, Wieckowski E, Wang GQ, Watkins SC, et al. Tumor-induced apoptosis of T cells: amplification by a mitochondrial cascade. Cancer Res 2000; 60: 6811-7.

[99] Buzyn A, Petit F, Ostankovitch M, Figueiredo S, Varet B, Guillet JG, et al. Membrane-bound Fas (Apo-1/CD95) ligand on leukemic cells: A mechanism of tumor immune escape in leukemia patients. Blood 1999; 94: 3135-40.

[100] Maeda H, Shiraishi A. TGF-beta contributes to the shift toward Th2-type responses through direct and IL-10-mediated pathways in tumor-bearing mice. J Immunol 1996; 156: 73-8.

[101] Lim SH, Worman CP, Jewell A, Goldstone AH. Production of tumour-derived suppressor factor in patients with acute myeloid leukaemia. Leuk Res 1991; 15: 263-8.

[102] Buggins AG, Milojkovic, Arno MJ, Lea NC, Mufti GJ, Thomas NS, et al. Microenvironment produced by acute myeloid leukemia cells prevents $\mathrm{T}$ cell activation and proliferation by inhibition of NF-kappaB, c-Myc, and pRb pathways. J Immunol 2001; 167: 6021-30

[103] Bruserud O, Ryningen A, Olsnes AM, Stordrange L, Oyan AM, Kalland KH, et al. Subclassification of patients with acute myelogenous leukemia based on chemokine responsiveness and constitutive chemokine release by their leukemic cells. Haematologica 2007; 92: 332-41.

[104] Olsnes AM, Motorin D, Ryningen A, Zaritskey AY, Bruserud O. T lymphocyte chemotactic chemokines in acute myelogenous leukemia (AML): local release by native human AML blasts and systemic levels of CXCL10 (IP-10), CCL5 (RANTES) and CCL17 (TARC). Cancer Immunol Immunother 2006; 55: 830-40.

[105] Nowbakht P, Ionescu PM, Rohner A, Kalberer CP, Rossy E, Mori $\mathrm{L}$, et al. Ligands for natural killer cell-activating receptors are expressed upon the maturation of normal myelomonocytic cells but at low levels in acute myeloid leukemias. Blood 2005; 105: 3615-22.

[106] Rohner A, Langenkamp U, Siegler U, Kalberer CP, WodnarFilipowicz A. Differentiation-promoting drugs up-regulate NKG2D ligand expression and enhance the susceptibility of acute myeloid leukemia cells to natural killer cell-mediated lysis. Leuk Res 2007.

[107] Ogbomo H, Michaelis M, Kreuter J, Doerr HW, Cinatl, J, Jr. Histone deacetylase inhibitors suppress natural killer cell cytolytic activity. FEBS Lett 2007; 581: 1317-22.

[108] Barry M, Bleackley RC. Cytotoxic T lymphocytes: all roads lead to death. Nat Rev Immunol 2002; 2: 401-9.

[109] Otten HG, van Ginkel WJ, Hagenbeek A, Petersen EJ. Prevalence and clinical significance of resistance to perforin- and FASmediated cell death in leukemia. Leukemia 2004; 18: 1401-5.

[110] Lehmann C, Zeis M, Schmitz N, Uharek L. Impaired binding of perforin on the surface of tumor cells is a cause of target cell resistance against cytotoxic effector cells. Blood 2000; 96: 594-600.

[111] Vollmer M, Li L, Schmitt A, Greiner J, Reinhardt P, Ringhoffer M, et al. Expression of human leucocyte antigens and co-stimulatory molecules on blasts of patients with acute myeloid leukaemia. $\mathrm{Br} \mathbf{J}$ Haematol 2003; 120: 1000-8. 
[112] Harris PE, Maffei A, Colovai AI, Kinne J, Tugulea S, Suciu-Foca N. Predominant HLA-class II bound self-peptides of a hematopoietic progenitor cell line are derived from intracellular proteins. Blood 1996; 87: 5104-12.

[113] Brouwer RE, Zwinderman KH, Kluin-Nelemans HC, van Luxemburg-Heijs SA, Willemze R, Falkenburg JH. Expression and induction of costimulatory and adhesion molecules on acute myeloid leukemic cells: implications for adoptive immunotherapy. Exp Hematol 2000; 28: 161-8.

[114] Chamuleau ME, Souwer Y, Van Ham SM, Zevenbergen A, Westers TM, Berkhof J, et al. Class II-associated invariant chain peptide expression on myeloid leukemic blasts predicts poor clinical outcome. Cancer Res 2004; 64: 5546-50.

[115] Graf M, Reif S, Hecht K, Pelka-Fleischer R, Kroell T, Pfister K, et al. High expression of costimulatory molecules correlates with low relapse-free survival probability in acute myeloid leukemia (AML). Ann Hematol 2005; 84: 287-97.

[116] Maeda A, Yamamoto K, Yamashita K, Asagoe M, Nohgawa K, Kita $\mathrm{K}$, et al. The expression of co-stimulatory molecules and their relationship to the prognosis of human acute myeloid leukaemia: poor prognosis of B7-2-positive leukaemia. Br J Haematol 1998; 102: $1257-62$.

[117] Hirano N, Takahashi T, Takahashi T, Ohtake S, Hirashima K, Emi $\mathrm{N}$, et al. Expression of costimulatory molecules in human leukemias. Leukemia 1996; 10: 1168-76.

[118] Pistillo MP, Tazzari PL, Palmisano GL, Pierri I, Bolognesi A, Ferlito F, et al. CTLA-4 is not restricted to the lymphoid cell lineage and can function as a target molecule for apoptosis induction of leukemic cells. Blood 2003; 101: 202-9.

[119] Laurent S, Palmisano GL, Martelli AM, Kato T, Tazzari PL, Pierri I, et al. CTLA-4 expressed by chemoresistant, as well as untreated, myeloid leukaemia cells can be targeted with ligands to induce apoptosis. Br J Haematol 2007; 136: 597-608.

[120] Saudemont A, Quesnel B. In a model of tumor dormancy, longterm persistent leukemic cells have increased B7-H1 and B7.1 expression and resist CTL-mediated lysis. Blood 2004; 104: 2124-33.

[121] Mackall CL. T-cell immunodeficiency following cytotoxic antineoplastic therapy: a review. Oncologist 1999; 4: 370-8.

[122] Behl D, Porrata LF, Markovic SN, Letendre L, Pruthi RK, Hook $\mathrm{CC}$, et al. Absolute lymphocyte count recovery after induction chemotherapy predicts superior survival in acute myelogenous leukemia. Leukemia 2006; 20: 29-34.

[123] Mackall CL, Fleisher TA, Brown MR, Andrich MP,Chen CC, Feuerstein IM, et al. Age, thymopoiesis, and CD4+ T-lymphocyte regeneration after intensive chemotherapy. N Engl J Med 1995; 332: 143-9.

[124] Fry TJ, Connick E, Falloon J, Lederman MM, Liewehr DJ, Spritzler J, et al. A potential role for interleukin-7 in T-cell homeostasis. Blood 2001; 97: 2983-90.

[125] Wendelbo O, Glenjen N, Bruserud O. Interleukin-7 (IL-7) in patients receiving intensive chemotherapy for acute myelogenous leukemia: studies of systemic IL-7 Levels and IL-7 responsiveness of circulating T lymphocytes. J Interferon Cytokine Res 2002; 22: $1057-65$.

[126] Rosenberg SA, Sportes C, Ahmadzadeh M, Fry TJ, Ngo LT, Schwarz SL, et al. IL-7 administration to humans leads to expansion of CD8+ and CD4+ cells but a relative decrease of CD4+ Tregulatory cells. J Immunother 2006; 29: 313-9.

[127] Wendelbo O, Nesthus I, Sjo M, Paulsen K, Ernst P, Bruserud O, Functional characterization of $\mathrm{T}$ lymphocytes derived from patients with acute myelogenous leukemia and chemotherapy-induced leukopenia. Cancer Immunol Immunother 2004; 53: 740-7.

[128] Mackall CL, Fleisher TA, Brown MR, Magrath IT, Shad AT, Horowitz ME, et al. Lymphocyte depletion during treatment with intensive chemotherapy for cancer. Blood 1994; 84: 2221-8.

[129] Bruserud O, Ulvestad E, Halstensen A, Berentsen S, Bergheim J, Nesthus I. Interleukin 4 responses in acute leukaemia patients with severe chemotherapy-induced leucopenia. Eur J Haematol 1997; 59: 269-76.

[130] Bruserud O, Ulvestad E, Berentsen S, Bergheim J, Nesthus I. Tlymphocyte functions in acute leukaemia patients with severe chemotherapy-induced cytopenia: characterization of clonogenic $\mathrm{T}$ cell proliferation. Scand J Immunol 1998; 47: 54-62.

[131] Bruserud O. Cellular immune responses in acute leukaemia patients with severe chemotherapy-induced leucopenia; characterization of the cytokine repertoire of clonogenic T cells. Cancer Immunol Immunother 1998; 46: 221-8.

[132] Bruserud O, Ulvestad E. Cytokine responsiveness of mitogenactivated $\mathrm{T}$ cells derived from acute leukemia patients with chemotherapy-induced leukopenia. J Interferon Cytokine Res 2000; 20: 947-54.

[133] Bruserud O, von Volkman HL, Ulvestad E. The cellular immune system of patients with acute leukemia and severe chemotherapyinduced leukopenia: characterization of T lymphocyte subsets responsive to IL-16 and IL-17. Acta Haematol 2000; 104: 80-91.

[134] Wendelbo O, Bruserud O. Fun ctional evaluation of proliferative T cell responses in patients with severe $\mathrm{T}$ lymphopen ia: characterization of optimal culture conditions and standardized activation signals for a simple whole blood assay. J Hematother Stem Cell Res 2003; 12: 525-35.

[135] Ersvaer E, Hampson P, Hatfield K, Ulvestad E, Wendelbo O, Lord $\mathrm{JM}$, et al. T cells remaining after intensive chemotherapy for acute myelogenous leukemia show a broad cytokine release profile including high levels of interferon-gamma that can be further increased by a novel protein kinase $\mathrm{C}$ agonist PEP005. Cancer Immunol Immunother 2007; 56: 913-25.

[136] Hakim FT, Memon SA, Cepeda R, Jones HEC, Chow CK, KastenSportes C, et al. Age-dependent incidence, time course, and consequences of thymic renewal in adults. J Clin Invest 2005; 115: 9309.

[137] Hirokawa K, Utsuyama M, Kasai M, Kurashima C, Ishijima S, Zeng YX. Understanding the mechanism of the age-change of thymic function to promote $\mathrm{T}$ cell differentiation. Immunol Lett 1994; 40: 269-77.

[138] Tosi P, Kraft R, Luzi P, Cintorino M, Fankhauser G, Hess MW, et al. Involution patterns of the human thymus. I Size of the cortical area as a function of age. Clin Exp Immunol 1982; 47: 497-504.

[139] Chidgey AP, Boyd RL. Stemming the tide of thymic aging. Nat Immunol 2006; 7: 1013-6.

[140] Terstappen LW, Huang S, Picker LJ. Flow cytometric assessment of human T-cell differentiation in thymus and bone marrow. Blood 1992; 79: 666-77.

[141] Theilgaard-Monch K, Raaschou-Jensen K, Palm H, Schjodt K, Heilmann C, Vindelov L, et al. Flow cytometric assessment of lymphocyte subsets, lymphoid progenitors, and hematopoietic stem cells in allogeneic stem cell grafts. Bone Marrow Transplant 2001; 28: 1073-82.

[142] Mackall CL,Bare CV, Granger LA, Sharrow SO, Titus JA, Gress RE. Thymic-independent $\mathrm{T}$ cell regeneration occurs via antigendriven expansion of peripheral $\mathrm{T}$ cells resulting in a repertoire that is limited in diversity and prone to skewing. J Immunol 1996; 156: 4609-16.

[143] Mackall CL, Granger L, Sheard MA, Cepeda R, Gress RE. T-cell regeneration after bone marrow transplantation: differential CD45 isoform expression on thymic-derived versus thymic-independent progeny. Blood 1993; 82: 2585-94.

[144] Heitger A, Greinix H, Mannhalter C, Mayerl D, Kern H, Eder J, et $a l$. Requirement of residual thymus to restore normal T-cell subsets after human allogeneic bone marrow transplantation. Transplantation 2000; 69: 2366-2373.

[145] Sutherland JS, Goldberg GL, Hammett MV, Uldrich AP, Berzins SP, Heng TS, et al. Activation of thymic regeneration in mice and humans following androgen blockade. J Immunol 2005; 175: 274153.

[146] Heng TS, Goldberg GL, Gray DH, Sutherland JS, Chidgey AP, Boyd RL. Effects of castration on thymocyte development in two different models of thymic involution. J Immunol 2005; 175: 298293.

[147] Goldberg GL, Sutherland JS, Hammet MV, Milton MK, Heng TS, Chidgey AT, et al. Sex steroid ablation enhances lymphoid recovery following autologous hematopoietic stem cell transplantation. Transplantation 2005; 80: 1604-13.

[148] Di Santo JP, Vosshenrich CA. Bone marrow versus thymic pathways of natural killer cell development. Immunol Rev 2006; 214 : 35-46.

[149] Porrata LF, Litzow MR, Tefferi A, Letendre L, Kumar S, Geyer $\mathrm{SM}$, et al. Early lymphocyte recovery is a predictive factor for prolonged survival after autologous hematopoietic stem cell transplantation for acute myelogenous leukemia. Leukemia 2002; 16: 13118. 
[150] Hokland P, Meyer K, Ellegaard J, Nielsen B, Hokland M. Distinct circulation patterns in peripheral blood of leukocyte subpopulations during the first 24 hours following autologous bone marrow transplantation. J Hematother 1996; 5: 647-54

[151] Storek J, Witherspoon RP, Storb R. T cell reconstitution after bone marrow transplantation into adult patients does not resemble $\mathrm{T}$ cell development in early life. Bone Marrow Transplant 1995; 16: 41325 .

[152] Guillaume T, Rubinstein DB, Symann M. Immune reconstitution and immunotherapy after autologous hematopoietic stem cell transplantation. Blood 1998; 92: 1471-90.

[153] Zambelli A, Montagna D, Da Prada GA, Maccario R, Zibera C, Moretta A, et al. Evaluation of infectious complications and immune recovery following high-dose chemotherapy (HDC) and autologous peripheral blood progenitor cell transplantation (PBPCT) in 148 breast cancer patients. Anticancer Res 2002; 22: 3701-8.

[154] Casorati G, Locatelli F, Pagani S, Garavaglia C, Montini E, Lisini $\mathrm{D}$, et al. Bone marrow-resident memory $\mathrm{T}$ cells survive pretransplant chemotherapy and contribute to early immune reconstitution of patients with acute myeloid leukemia given mafosfamide-purged autologous bone marrow transplantation. Exp Hematol 2005; 33: 212-8.

[155] Tayebi H, Kuttler F, Saas P, Lienard A, Petracca B, Lapierre V, et al. Effect of granulocyte colony-stimulating factor mobilization on phenotypical and functional properties of immune cells. Exp Hematol 2001; 29: 458-70.

[156] Rutella S, Pierelli L, Bonanno G, Sica S, Ameglio F, Capoluongo $\mathrm{E}$, et al. Role for granulocyte colony-stimulating factor in the generation of human T regulatory type 1 cells. Blood 2002; 100: 256271 .

[157] Singh RK, Varney ML, Ino K, Vose JM, Bierman PJ, Talmadge JE. Immune dysfunction despite high levels of immunoregulatory cytokine gene expression in autologous peripheral blood stem cell transplanted non-Hodgkin's lymphoma patients. Exp Hematol 2000; 28: 499-507.

[158] Sloand EM, Kim S, Maciejewski JP, Van Rhee F, Chaudhuri A, Barrett $\mathrm{J}$, et al. Pharmacologic doses of granulocyte colonystimulating factor affect cytokine production by lymphocytes in $v i$ tro and in vivo. Blood 2000; 95: 2269-74.
[159] Vela-Ojeda J, Esparza MA, Reyes-Maldonado E, JimenezZamudio L, Garcia-Latorre E, Moreno-Lafont M, et al. CD4+ CD25+ lymphocyte and dendritic cell mobilization with intermediate doses of recombinant human granulocyte colony-stimulating factor in healthy donors. Stem Cells Dev 2005; 14: 310-6.

[160] Abrahamsen IW, Somme S, Heldal D, Egeland T, Kvale D, Tjonnfjord GE. Immune reconstitution after allogeneic stem cell transplantation: the impact of stem cell source and graft-versus-host disease. Haematologica 2005; 90: 86-93.

[161] Kim DH, Sohn SK, Won DI, Lee NY, Suh JS, Lee KB. Rapid helper T-cell recovery above $200 \times 106 / 1$ at 3 months correlates to successful transplant outcomes after allogeneic stem cell transplantation. Bone Marrow Transplant 2006; 37: 1119-28

[162] Ruggeri L, Mancusi A, Capanni M, Urbani E, Carotti A, Aloisi T, et al. Donor natural killer cell allorecognition of missing self in haploidentical hematopoietic transplantation for acute myeloid leukemia: challenging its predictive value. Blood 2007.

[163] Kolb HJ, Schmid C, Barrett AJ, Schendel DJ. Graft-versusleukemia reactions in allogeneic chimeras. Blood 2004; 103: 767 76.

[164] Kroger N, Binder T, Zabelina T, Wolschke C, Schieder H, Renges $\mathrm{H}$, et al. Low number of donor activating killer immunoglobulinlike receptors (KIR) genes but not KIR-ligand mismatch prevents relapse and improves disease-free survival in leukemia patients after in vivo T-cell depleted unrelated stem cell transplantation. Transplantation 2006; 82: 1024-30.

[165] Farag SS, Bacigalupo A, Eapen M, Hurley C, Dupont B, Caligiuri MA, et al. The effect of KIR ligand incompatibility on the outcome of unrelated donor transplantation: a report from the center for international blood and marrow transplant research, the European blood and marrow transplant registry, and the Dutch registry. Biol Blood Marrow Transplant 2006; 12: 876-84

[166] Arina A, Murillo O, Dubrot J, Azpilikueta A, Alfaro C, PerezGracia GL, et al. Cellular liaisons of natural killer lymphocytes in immunology and immunotherapy of cancer. Expert Opin Biol Ther 2007; 7: 599-615.

[167] Bryceson YT, March ME, Ljunggren HG, Long EO. Activation, coactivation, and costimulation of resting human natural killer cells. Immunol Rev 2006; 214: 73-91. 